\title{
Environmental factors in trade during the great transformation: advancing the geographical coverage before 1950
}

\author{
John Brolin* and Astrid Kander \\ Department of Economic History, Lund University, P.O. Box 7083, SE-22007 Lund, Sweden \\ ${ }^{\star}$ Corresponding author. Emails: john.brolin@ekh.lu.se; astrid.kander@ekh.lu.se
}

\begin{abstract}
In the study of trade-embedded environmental factors (land, water, energy, or material flows), three conflicting interpretations prevail concerning what happened before 1950. The 'great specialization' narrative argues that trade served to lighten pressure on the environment by redistributing environmental services from where they were abundant to where they were scarce. The 'great divergence' sees an exploitative transfer from poor countries to rich and powerful ones or an environmental load displacement from rich to poor. The 'great acceleration' dismisses flows as insignificant either way. We review long-term national studies and find an almost exclusive focus on developed countries, mostly European and especially the UK, where more systematic studies tend to support 'specialization' and/or 'acceleration'. By contrast, more qualitative studies on individual exports from developing countries often support 'divergence', but, since imports are excluded by design, this can never be demonstrated. We propose widening the geographical scope of long-term national studies beyond Europe and extending existing studies with bilateral trade, and suggest that 'developing country' trade be quantified according to existing methods of environmental accounting.
\end{abstract}

Keywords: ecologically unequal exchange; factor trade; global environmental change; globalization; ghost acreage

\section{Introduction}

Over the past two centuries, industrial production, facilitated communications and voluminous trade have transformed societies into something previously unknown: a global industrial civilization, unique both in its intricate global integration of production and consumption through trade $^{1}$ and through humanity's emergence as a dominant environmental, even geological force. ${ }^{2}$ The study of trade-embedded environmental factors - materials contained within traded goods, or land, energy, water, and pollutants used or emitted in their production - is important in understanding the global redistribution of environmental goods and burdens between regions with different endowments and levels of income. The conventional way to assess human impact on the environment is to measure and add up how much is caused by the production within

\footnotetext{
${ }^{1} \mathrm{R}$. E. Baldwin, The great convergence: information technology and the new globalization, Cambridge, MA: The Belknap Press, 2016; R. Findlay and K. H. O'Rourke, Power and plenty: trade, war, and the world economy in the second millennium, Princeton, NJ: Princeton University Press, 2007; K. H. O'Rourke and J. G. Williamson, Globalization and history: the evolution of a nineteenth-century Atlantic economy, Cambridge, MA: MIT Press, 1999; J. Osterhammel, The transformation of the world: a global history of the nineteenth century, Princeton, NJ: Princeton University Press, 2014.

${ }^{2}$ S. L. Lewis and M. A. Maslin, 'Defining the Anthropocene', Nature, 519, 2015, pp. 171-80; J. R. McNeill, 'Energy, population, and environmental change since 1750: entering the Anthropocene', in J. R. McNeill and K. Pomeranz, eds., Cambridge world history, vol. 7: production, destruction, and connection, 1750-present, Cambridge: Cambridge University Press, 2015 , pp. 5-82.

(C) The Author(s), 2020. Published by Cambridge University Press. This is an Open Access article, distributed under the terms of the Creative Commons Attribution-NonCommercial-ShareAlike licence (http://creativecommons.org/licenses/by-nc-sa/4.0/), which permits non-commercial re-use, distribution, and reproduction in any medium, provided the same Creative Commons licence is included and the original work is properly cited. The written permission of Cambridge University Press must be obtained for commercial re-use.
} 
nations, but without considering where products finally end up. Such global production-based accounts often reach back to 1850 or earlier. ${ }^{3}$ Since the environmental impacts caused by the production of some nations can serve the consumption of others, efforts have been made to assess how much of a nation's environmental impact is contained within its exports compared to its imports. However, global studies of trade-embedded environmental factors and consumption-based accounts are at best limited to the period after around 1950. ${ }^{4}$ This has left a century-long knowledge gap that is currently filled with much speculation but little actual data - precisely for a crucial period in the formation of global industrial civilization when production and consumption were becoming spatially separated on a global scale and international levels of income diverged.

One way in which the temporal gap can be bridged is through a multiplication of long-term national consumption-based accounts or quantitative studies of trade-embedded environmental factors. The recent article in Journal of Global History by Theodoridis, Warde, and Kander is an important contribution to start filling this void. ${ }^{5}$ Yet, no comprehensive review exists of the current state of knowledge about long-term (pre-1950) trade-embedded impacts, and this is what we aim to provide in this article. The goal is to establish a more solid empirical foundation on which to base historical storytelling, but more specifically to point out where the gaps in knowledge are, and to suggest how they can be filled.

The vague state of knowledge of environmental flows in trade before 1950 is regrettable, since many ideas about the current state of the world, such as why some countries are rich and others are poor, make strong assumptions and assertions about trade-embedded environmental factors for much earlier times. A case in point is an interesting attempt by Muradian, Walter, and Martinez-Alier to historically contextualize the rise of China as a global 'hegemon'. Citing empirical estimates of recent material flows and improving terms of trade for raw materials, they suggest that this would be 'the first time that the rise of a new hegemon of global capitalism is associated with very favorable conditions for the peripheries that play the role of suppliers of natural resources'. ${ }^{6}$ No corresponding empirical evidence is cited relating to the rise of the other hegemons, the UK or the US, although these are indeed among the few cases for which nineteenth-century physical trade balances have been estimated.

Much like medieval and early modern cartographers who filled their maps with monsters and unknown continents, modern scholars tend to fill up the knowledge gap of previous centuries according to their preconceptions. We discern three conflicting narratives that are in dire need of more empirical facts and investigations to support, refute, or refine them.

What we term the 'great specialization" ${ }^{\text {"7 }}$ narrative argues that trade served to ease the pressure on the environment by redistributing environmental services from where they were abundant to where they were scarce. By allowing specialization to take place where natural resources are most abundant or use is most efficient, trade may allow global savings on the environment that benefit all trading parties, just as in David Ricardo's famous example illustrating the mainstream economic theory of 'comparative advantage'. ${ }^{8}$ Transfers of natural resources and embedded emissions are thus said to follow the patterns to be expected from the factor endowments of

${ }^{3}$ J. Brolin and A. Kander, 'Global trade and the Anthropocene: environmental factor flows during the Great Acceleration', unpublished manuscript.

${ }^{4}$ Ibid.

${ }^{5}$ D. Theodoridis, P. Warde, and A. Kander, 'Trade and overcoming land constraints in British industrialization: an empirical assessment', Journal of Global History, 13, 3, 2018, pp. 328-51.

${ }^{6} \mathrm{R}$. Muradian, M. Walter, and J. Martinez-Alier, 'Hegemonic transitions and global shifts in social metabolism: implications for resource-rich countries', Global Environmental Change, 22, 2012, pp. 562-3.

${ }^{7}$ D. H. Robertson, 'The future of international trade', Economic Journal, 48, 189, 1938, p. 6; Findlay and O'Rourke, Power and plenty, p. 411.

${ }^{8}$ D. Ricardo, The principles of political economy and taxation, in P. Sraffa and M. Dobb, eds., Works and correspondence of David Ricardo, vol. 1, Cambridge: Cambridge University Press, 1951 (original 3rd edn 1821). 
particular countries, and the savings made from trade are regarded as a source of economic growth and/or efficient use of nature. ${ }^{9}$ Such savings are not incommensurable with unbalanced net flows (meaning imports minus exports). Indeed, theoretically, optimal specialization even requires unbalanced factor flows. ${ }^{10}$

The 'great divergence'11 narrative sees a geographical displacement of environmental burdens from developed countries to their peripheries or an exploitative transfer from poor countries to rich and powerful ones. The acquisitiveness of the West over the past five centuries and its global hunt for riches and resources around the world is an important motivation behind many environmental studies of individual exports from less-developed countries. ${ }^{12}$ Transfers of peripheral natural resources, and their associated environmental burdens, are seen as a cause and consequence of global inequalities. The correlation between specialization in raw material production and slower economic growth has suggested the existence of a 'natural resource curse'. ${ }^{13}$ The so called Prebisch-Singer theorem from the 1950s argues that exchanging raw materials for manufactures is disadvantageous. ${ }^{14}$ Related theories of 'ecologically unequal exchange' claim that a net flow of natural resources from poor to rich countries, displacing the environmental burdens of development from rich to poor, follow from the nature of extractive versus industrial economies or even the 'thermodynamics' of the global production chain. $^{15}$

The 'great acceleration'16 narrative dismisses historical flows as being insignificant either way. It draws support from the strong increase in global environmental factor flows in recent decades, leading some scholars to conclude that earlier transfers were so small that they can safely be ignored. ${ }^{17}$ This is the implicit assumption among most scholars focusing on current events, but partially supported also by prominent economic historians who refer to the alleged reliance of developed countries on 'Third World' resources as a myth. ${ }^{18}$

One reason for the simultaneous proliferation of these conflicting narratives is a lack of systematic empirical data on flows of environmental factors in the long nineteenth-century 'great transformation' (preceding the post-war 'great acceleration'), in which both the 'great divergence'

${ }^{9}$ R. Findlay and M. Lundahl, The economics of the frontier: conquest and settlement, Basingstoke: Palgrave Macmillan, 2017; Findlay and O'Rourke, Power and plenty.

${ }^{10} \mathrm{~J}$. Vanek, 'The factor proportions theory: the N-factor case', Kyklos, 21, 1968, pp. 749-55.

${ }^{11} \mathrm{~K}$. Pomeranz, The great divergence: China, Europe, and the making of the modern world economy, Princeton, NJ: Princeton University Press, 2000.

${ }^{12} \mathrm{~J}$. R. Richards, The unending frontier: an environmental history of the early modern world, Berkeley, CA: University of California Press, 2005; R. P. Tucker, Insatiable appetite: the United States and the ecological degradation of the tropical world, Berkeley, CA: University of California Press, 2000; J. W. Moore, 'The modern world-system as environmental history? Ecology and the rise of capitalism', Theory and Society, 32, 2003, pp. 307-77.

${ }^{13}$ M. Badia-Miró, V. Pinilla, and H. Willebald, eds., Natural resources and economic growth: learning from history, London: Routledge, 2015.

${ }^{14} \mathrm{~J}$. Brolin, The bias of the world: theories of unequal exchange in history, Lund: Studentlitteratur, 2006.

${ }^{15} \mathrm{~S}$. G. Bunker, 'Modes of extraction, unequal exchange, and the progressive underdevelopment of an extreme periphery: the Brazilian Amazon, 1600-1980', American Journal of Sociology, 89, 5, 1984, pp. 1017-64; S. G. Bunker, Underdeveloping the Amazon: extraction, unequal exchange, and the failure of the modern state, Chicago, IL: University of Chicago Press, 1985; M. Cabeza-Gutes and J. Martinez-Alier, 'L'échange ecologiquement inégal', in M. Damian and J.-C. Graz, eds., Commerce international et developpement soutenable, Paris: Economica, 2001, pp. 159-85; A. Hornborg, 'Towards an ecological theory of unequal exchange: articulating world system theory and ecological economics', Ecological Economics, 25, 1, 1998, pp. 127-36.

${ }^{16} \mathrm{~J}$. R. McNeill, and P. Engelke, The great acceleration: an environmental history of the Anthropocene since 1945, Cambridge, MA: The Belknap Press, 2014.

${ }^{17}$ Z. Yang, T. Wei, J. C. Moore, J. Chou, W. Dong, R. Dai, S. Yang, and J. Ban, 'A new consumption-based accounting model for greenhouse gases from 1948 to 2012', Journal of Cleaner Production 133, 2016, pp. 368-77.

${ }^{18} \mathrm{P}$. Bairoch, Economics and world history: myths and paradoxes, Chicago, IL: University of Chicago Press, 1993; W. A. Lewis, Growth and fluctuations, 1870-1913, London: George Allen \& Unwin, 1978. 
(between rich and poor nations) and the 'great specialization' (between primary and secondary producers) unfolded on a global scale. ${ }^{19}$

If the global share of trade-embedded to total environmental impact is similar to the share of exports to GDP - presently about a quarter to a third for both, and with similar rising trends since the Second World War - then shares in 1913 (c.15\%) were higher than at any time until the 1970 s. ${ }^{20}$ For many issues, however, the central concern is not over the scale of flows compared with more recent dates, but over what the differences in existing flows tell us about the processes involved: for example, whether 'unequal exchange' or 'comparative advantage' has been predominant. Kenneth Pomeranz's much-debated book, The great divergence, renewed the central question of development economics and economic history on the roots of global inequality between nations, arguing that, if we look at China (and perhaps other Asian countries), the great divergence was still not visible in 1800. Its unfolding over the nineteenth and early twentieth centuries was made possible only through the transfer of trade-embedded land ('ghost acres') from overseas. Notably, however, this still leaves open the question whether these transfers represent 'unequal exchange' or 'comparative advantage' - whether they followed the logic of divergence or simply of specialization.

The fact that both ecologically unequal exchange and comparative advantage assume unequal net flows of environmental factors indicates the need for a stricter formulation of unequal exchange, specifying situations where the predicted flows differ from those anticipated by the specialization narrative. This point was made explicitly by Arghiri Emmanuel as an argument for only considering as 'unequal' the share of factor flows resulting from an institutional income differential. This share may very well be greater than net flows, which, by contrast, also depend on differences in endowments and efficiency, which may either reinforce or counteract the imbalance due to income. ${ }^{21}$

Unfortunately, quantifying these shares involves large methodological challenges for empirical studies. Instead, determining more specifically the geographical directions of various environmental factor flows would at least be suggestive of the underlying causes, namely, whether they tend to flow from 'peripheries' with scarce populations to 'centres' with dense populations, independently of respective level of income, or whether they tend to flow from 'peripheries' with low income to 'centres' with high income, irrespective of population density. And so on, if possible, for differences in environmental efficiency (technologies).

All these elements are presumably active simultaneously, differing only in relative importance, possibly among indicators or between different waves of globalization. There is, in our view, no reason to suppose that environmental savings from trade are incompatible with unequal exchange in the stricter sense, thus opening the horizon for stories that transcend those outlined above. Our review will only indicate where results suggest one or other conclusion, without the ambition to solve the fundamental puzzle.

Quantitative national studies of trade-embedded environmental factors in the period before 1950 are mostly extensions of long-term national research reflecting the geographical origin of the researching institution. Researchers tend to start with their own country, for which they have knowledge of national statistical sources, and then expand it to a comparison with the UK and then other developed countries. This pattern repeats itself for Austrian studies of material flows, Swedish studies of embedded energy and carbon dioxide, and Spanish studies of the wood trade.

\footnotetext{
${ }^{19}$ This is not meant to express any opinion on whether the origins of the 'great divergence' can first be discerned before or after 1800 .

${ }^{20}$ Brolin and Kander, 'Global trade'.

${ }^{21}$ A. Emmanuel, Unequal exchange: a study of the imperialism of trade, New York: Monthly Review Press 1972; Brolin, Bias of the world; J. Brolin, 'Unequal exchange', in I. Ness and Z. Cope, eds., The Palgrave encyclopedia of imperialism and anti-imperialism, Basingstoke: Palgrave Macmillan, 2016, pp. 1160-77.
} 


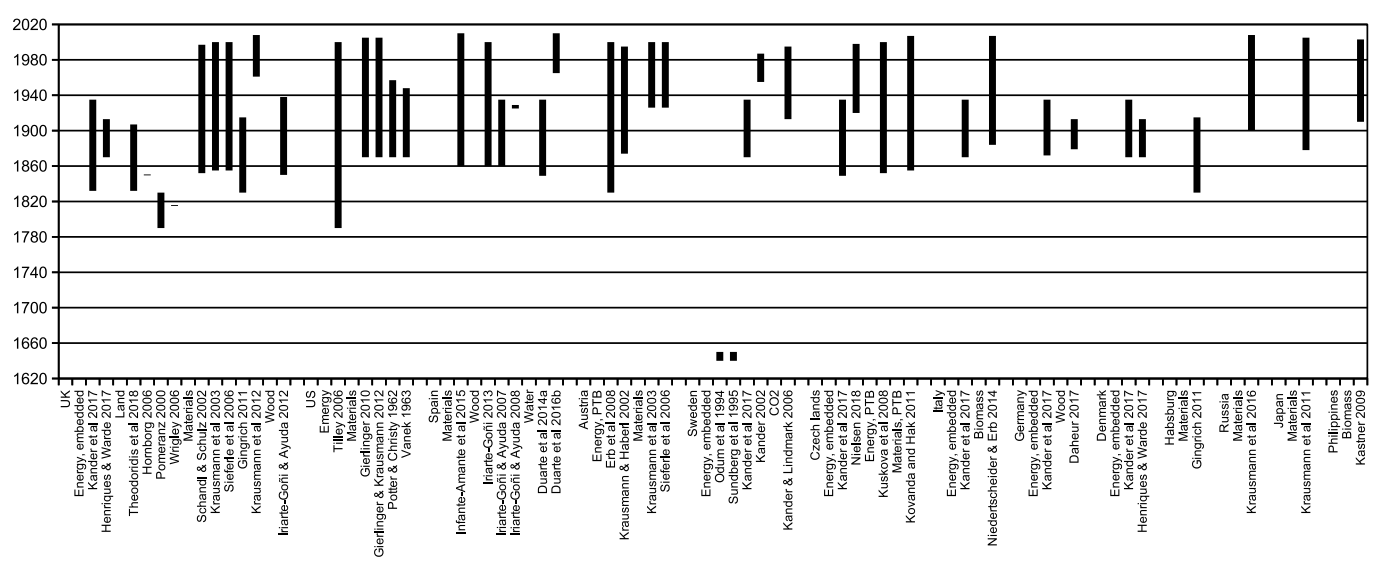

Figure 1. Long-term national studies of trade-embedded environmental factors, 1620-2020.

This explains why the UK is best represented in historical studies, followed by other developed countries (see figure 1$){ }^{22}$

Our review will start with the UK and expand from there, including a section on non-quantitative studies of peripheral regions. We will conclude with suggestions for future study.

\section{Trade-embedded land in UK historical debates}

The UK is the lead character in the stories told both of divergence and of specialization - and probably the best case arguing against only a recent great acceleration. Debates by historians have mostly centred on trade-embedded land ('ghost acres' or 'ecological footprints'). As the UK is a densely populated island, land scarcity was a limiting factor for its economic development, with two means of accessing more land: horizontal expansion (trade and colonization) and vertical expansion (digging for land-substituting energy carriers such as coal). If coal was the dominant factor, as argued by Wrigley, this speaks in favour of the 'great specialization' according to endowments; if trade-embedded imports of land were predominant, as held by Pomeranz, this still leaves open the 'great divergence' perspective. ${ }^{23} \mathrm{~A}$ more unequivocal, albeit eccentric, 'divergence' stance is taken by Hornborg, who maintains the necessity of ecologically unequal exchange of land (and labour) for technological development in general, and for British industrialization in particular. ${ }^{24}$ The currently most comprehensive estimate of trade-embedded land, by Theodoridis, Warde, and Kander, favours instead the specialization narrative. ${ }^{25}$

Borgström's concept of 'ghost acreage' was introduced into historical debates by Jones, who identified four main ecological zones adding to Europe's 'great frontier': ocean fisheries, notably the cod fisheries of the Grand Banks; the boreal woods around the Baltic, adding forest products and grain; tropical and subtropical lands, adding goods such as tobacco, indigo, rice, sugar, and

\footnotetext{
${ }^{22}$ Studies have been included if they contain quantitative estimates of international flows of an environmental indicator on a national level before 1950 (or if an author of a pre-1950 study has also written on the same geographical area and indicator for the post-1950 period).

${ }^{23} \mathrm{E}$. A. Wrigley, 'The transition to an advanced organic economy: half a millennium of English agriculture', Economic History Review, 59, 3, 2006, pp. 435-80; Pomeranz, Great divergence.

${ }^{24}$ A. Hornborg, 'Footprints in the cotton fields: the Industrial Revolution as time-space appropriation and environmental load displacement', Ecological Economics, 59, 2006, pp. 74-81.

${ }^{25}$ Theodoridis, Warde, and Kander, 'Trade and overcoming'; see also D. Theodoridis, Development constrained: essays on land as a factor in nineteenth-century industrialization and trade, Gothenburg Studies in Economic History 19, Gothenburg: University of Gothenburg, 2018.
} 
cotton; and temperate North America, the grasslands of South America, South Africa, Australia, and the steppes of southern Russia, which became immense sources of grain (as well as meat, wool, and other animal products). ${ }^{26}$ These frontiers, especially the last, are reflected in the geographical origins of UK land imports in the nineteenth and early twentieth centuries. ${ }^{27}$

Inspired by Wrigley's early study on the supply of coal in the Industrial Revolution, Jones noted how coal mining extended the resource frontier vertically into the interior of the earth, adding a 'coal acreage', calculated as the additional acreage that would have been needed, with known technologies of the time, to produce the charcoal and firewood energy and organic chemicals for which coal provided a substitute. ${ }^{28}$ The suggestion to translate coal into an acreage was again taken up by Wrigley, who estimated (based on 2 tons of wood fuel/acre) that the coal produced in 1700 corresponded to adding 2.5-3 million acres of woodland, and by 1815 this had increased to 15 million acres. ${ }^{29}$ Pomeranz picked up the argument from Jones on the importance of trade compared to coal, but added actual empirical estimates of the 'ghost acres' contained in British imports. He suggested that the 1815 coal acreage should be revised upwards to 21 million acres (based on 1.45 tons of wood fuel/acre), but argued that its importance was still smaller than the ghost acres within imports of timber, sugar, and cotton, which totalled about 25-30 million acres in $18300^{30}$ Theodoridis, Warde, and Kander point out that Pomeranz's comparison is skewed against coal, since by 1830 coal production had almost doubled compared to 1815 , and also argue that 0.85 tons of wood fuel/acre would be more accurate for a sustainable yield, which makes the coal acreage much larger than the trade acreage. ${ }^{31}$

Table 1 reports existing land estimates for UK imports and exports, starting with Pomeranz's three product groups, followed by those added by Hornborg and by Theodoridis, Warde, and Kander. The estimates for wood in the table present a fairly consistent pattern, rising from about 1 million acres to 15 million acres over the century after 1830 . Pomeranz estimated the land area required for Baltic timber exports to the UK in the 1780s to about 650,000 acres and North American in 1825 to 1 million acres, after which they soared. ${ }^{32}$ Theodoridis, Warde, and Kander's estimate for 1832 is somewhat lower, but the rise over the century is otherwise consistent with other estimates. ${ }^{33}$ Iriarte-Goñi and Ayuda report annual net imports (in cubic metres) of solid wood in 1850-1938 and wood pulp in 1885-1938, as well as the ratio of home grown timber to total consumption. Imports increased their share from about $50 \%$ in the 1850 s to almost $90 \%$ in the 1930s, so the UK was highly dependent on international trade for its wood requirements. By 1850 wood had already ceased to be important as a source of energy in the UK, and was declining in shipbuilding. Use continued in old and expanding construction and furniture industries, and as a new raw material for paper, so its overall importance did not decline. Net imports of solid wood increased from 2.5 million cubic metres in 1850 to 15.5 million cubic metres in 1913 ,

\footnotetext{
${ }^{26} \mathrm{G}$. Borgström, The hungry planet: the modern world at the edge of famine, New York: Macmillan, 1965; E. L. Jones, The European miracle: environments, economies and geopolitics in the history of Europe and Asia, Cambridge: Cambridge University Press, 1981.

${ }^{27}$ Theodoridis, Development constrained.

${ }^{28} \mathrm{E}$. A. Wrigley, 'The supply of raw materials in the Industrial Revolution', Economic History Review, 15, 1, 1962, pp. 1-16; see also W. R. Catton, Overshoot: the ecological basis of revolutionary change, Urbana, IL: University of Illinois Press, 1982; R. P. Sieferle, The subterranean forest: energy systems and the Industrial Revolution, Cambridge, MA: The White Horse Press, 2001.

${ }^{29}$ E. A. Wrigley, Continuity, chance, and change: the character of the Industrial Revolution in England, Cambridge: Cambridge University Press, 1988.

${ }^{30}$ Pomeranz, Great divergence, pp. 275-6 and appendix D.

${ }^{31}$ Theodoridis, Warde, and Kander, 'Trade and overcoming'.

${ }^{32}$ Pomeranz, Great divergence.

${ }^{33}$ Theodoridis, Warde, and Kander, 'Trade and overcoming'. According to B. W. Clapp, An environmental history of Britain since the Industrial Revolution, London: Longman, 1994, p. 107, timber imports to the UK trebled between 1864 and 1899 , when they reached 10 million tons, and, together with imports of wood pulp, corresponded to 9 million acres of woodland from temperate areas.
} 
Table 1. Trade-embedded land (million acres) in selected UK traded goods

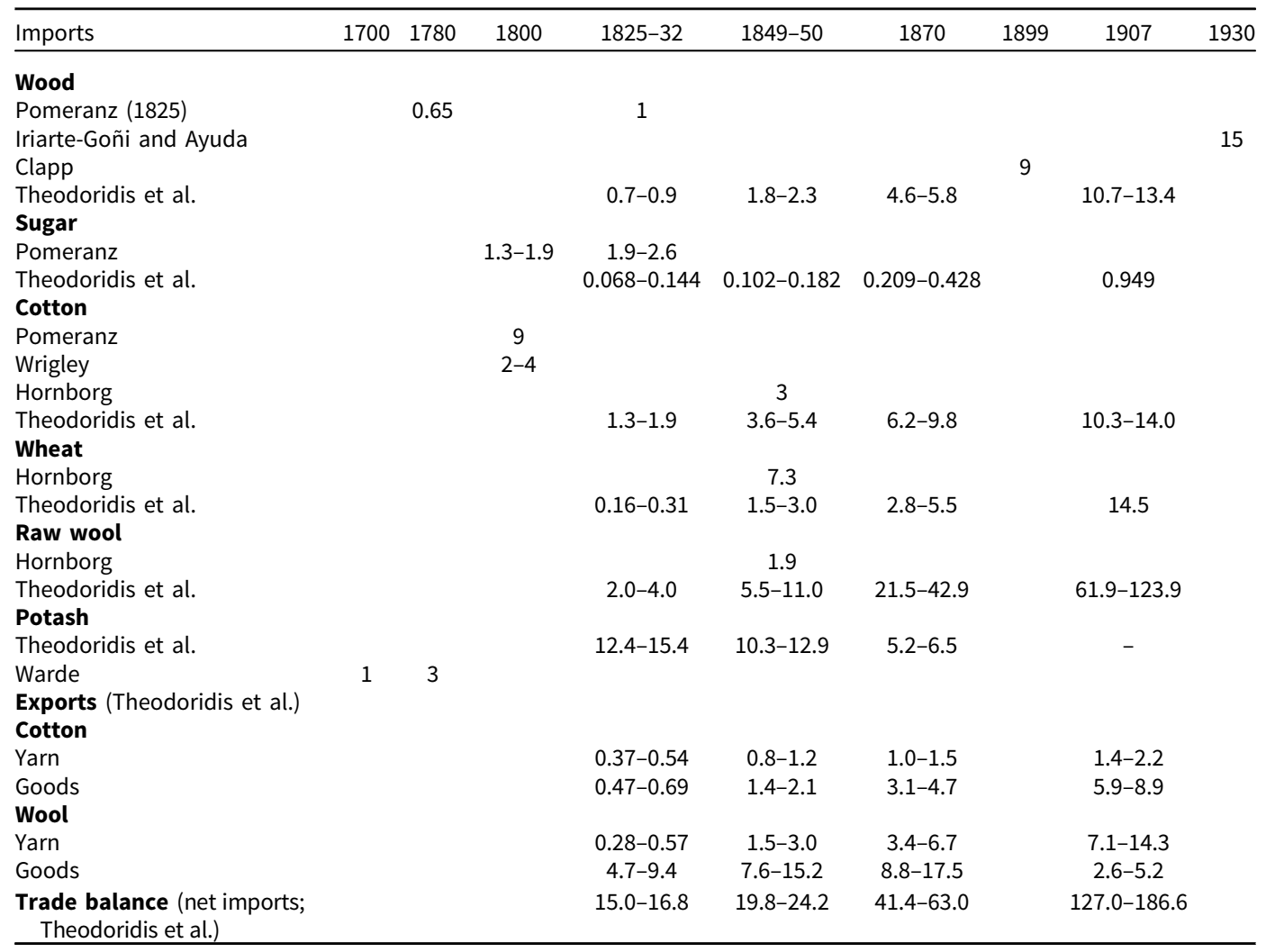

Sources: Clapp, Environmental history; Hornborg, 'Footprints'; Iriarte-Goñi and Ayuda, 'Not only subterranean forests'; Pomeranz, Great divergence; Theodoridis, Warde, and Kander, 'Trade and overcoming'; P. Warde, 'Trees, trade and textiles: potash imports and ecological dependency in British industry, c. 1550-1770', Past \& Present, 240, 2018, pp. 47-82; Wrigley, 'Transition'.

and fluctuated around this value in the interwar years. Net imports of wood pulp increased tenfold from 0.6 million cubic metres in 1885 to 6.1 million cubic metres in 1913, and about doubled again before the Second World War. By the 1930s, assuming a global productivity of 1.82 cubic metres per acre, Iriarte-Goñi and Ayuda estimated the ghost acreage for wood at about

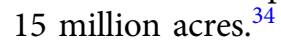

Caribbean sugar has figured prominently in narratives on the importance of peripheral goods for the British Industrial Revolution, and sugar is the only one of Pomeranz's products that has a predominantly 'Third World' origin (at least until the domestic production of beet sugar took off during the nineteenth century). Pomeranz's estimates (in appendix D) are based on two assumptions: first, that $4 \%$ of total calorific intake comes from sugar; second, that calories from imported sugar would have to be supplied from alternative domestic sources, in his case wheat. Because Caribbean sugar cane yields many more calories per acre than does British wheat, these areas become vast: 1.3-1.9 million acres were imported in 1800 and 1.9-2.6 million acres in $1831 .{ }^{35}$ Wrigley points out that this seems excessive, since the

\footnotetext{
${ }^{34}$ I. Iriarte-Goñi and M.-I. Ayuda, 'Not only subterranean forests: wood consumption and economic development in Britain (1850-1938)', Ecological Economics, 77, 2012, pp. 176-84.

${ }^{35}$ Pomeranz, Great divergence, p. 275 (in appendix D the figures are somewhat lower).
} 
remaining 96\% non-sugar calories would have required many more acres devoted to cereal production than actually used - more precisely, 31.2-45.6 million acres (using Pomeranz's figures on p. 275) compared to the actual total arable acreage in England and Wales, which was only 11.5 million acres. ${ }^{36}$ Theodoridis, Warde, and Kander instead use actual sugar acreage, which is minuscule by comparison - some eighteen to twenty-six times lower in 1832 (see table 1$).^{37}$

Pomeranz's raw cotton acreage is also based on a counterfactual scenario where domestically produced goods have replaced imports. Since cotton cannot be grown in Britain, he instead calculated how much wool would have been needed to replace cotton, and the area needed to produce that wool, about 9 million acres in 1800. However, Wrigley pointed out that wool farms had multiple outputs (such as meat), of which wool monetarily only constituted $18-45 \%$. He correspondingly downsized the number to $2-4$ million acres. ${ }^{38}$ Using instead the actual land required for cotton production, and raw cotton land requirements of 12.2 acres per ton from the American South, Hornborg estimated that British imports corresponded to about 3 million acres in $1850 .{ }^{39}$ Also using actual land requirements, Theodoridis, Warde, and Kander found that ghost acres in cotton imports amounted to 3.6-5.4 million acres in 1849, after almost tripling since 1832 , and that they then tripled again by $1907.4^{40}$

We see that using actual rather than 'counterfactual' land results in much lower estimates. This difference resembles how 'gains from trade' are calculated in the tradition of Ricardo's comparative advantage, meaning that the UK saved much more land through trade than was used by its trading partners, resulting in an overall gain from trade.

The same is true for wheat. Hornborg found that wheat imports to Britain from Germany and Russia amounted to 7.3 million imported acres in $1850,{ }^{41}$ whereas Theodoridis, Warde, and Kander only found wheat imports to equal 1.5-3.0 million acres by 1849 (despite a tenfold increase since 1832). ${ }^{42}$ The difference is explained by Hornborg using counterfactual (lower) British yields for imports as well, whereas Theodoridis, Warde, and Kander use the actual (higher) yields of the exporting regions, which results in lower imported acreage. Again, this difference can be interpreted as 'gains from trade', whereas Hornborg, focusing on net flows, instead finds 'ecologically unequal exchange'. By 1870, at the beginning of the great 'grain invasion', imported wheat acreage had already almost doubled, and by 1907 it had reached 14.5 million acres (using area-specific conversion factors). ${ }^{43}$ Thus, in 1907, wood, cotton, and wheat each supplied about as much as the domestic acreage of arable land, between 10 and 15 million acres.

These numbers - large as they may seem - nevertheless dwindle by comparison to wool, which in Theodoridis, Warde, and Kander's estimate rose tenfold from 1832 to 1870, then tripled again by 1907 , reaching some $60-120$ million acres. ${ }^{44}$ Hornborg found imports of raw wool corresponding to almost 2 million acres in 1850, using British yields. ${ }^{45}$ However, according to Theodoridis, Warde, and Kander, sheep needed much more grazing land to produce wool, so that the net imports of raw wool become correspondingly (three to six times) higher.

In addition to these previously debated commodities, Theodoridis, Warde, and Kander estimated land requirements for numerous other traded goods. One startling result is that UK imports of potash were by far the largest source of ghost acreage in both 1832 and 1849, after

\footnotetext{
${ }^{36}$ Wrigley, 'Transition', p. 471.

${ }^{37}$ The data on sugar was provided by Theodoridis, personal communication, 26 March 2018.

${ }^{38}$ Wrigley, 'Transition'.

${ }^{39}$ Hornborg, 'Footprints'.

${ }^{40}$ Theodoridis, Warde, and Kander, 'Trade and overcoming'.

${ }^{41}$ Hornborg, 'Footprints'.

${ }^{42}$ Theodoridis, Warde, and Kander, 'Trade and overcoming'.

${ }^{43}$ Ibid.

${ }^{44} \mathrm{Ibid}$.

${ }^{45}$ Hornborg, 'Footprints'.
} 
which their importance declined considerably, when coal could be used to produce soap. ${ }^{46}$ While the production of potash may have involved burning down whole forests and gathering the ashes, Theodoridis, Warde, and Kander assume sustainable yields for the production of potash, not the actual forested area cleared. They also assume that potash was the principal output from this land from the UK perspective (not accounting for the ash possibly remaining on the land as fertilizer). Warde has recently estimated the extent of important English potash imports long before the nineteenth century, then mostly from the Baltic area, rising from around 1 million acres in 1700 to 3 million acres by 1790 - much more than the total from the colonial food and fibres estimated by Pomeranz. ${ }^{47}$ Over the nineteenth century, the expanding US frontier grew in importance, where exports of potash helped farmers pay for the clearing of land for agriculture (itself considered an economic value). US exports declined suddenly from 24,219 tons in 1844 to a mere 2,633 tons by $1864-65$ with the discovery of alternative mineral sources, ${ }^{48}$ and the potash acreage of British imports also subsequently declined. If the great potash imports from the US and the Baltic states suggest that until the mid nineteenth century the UK unburdened itself of an environmental load, their later substitution by domestic sources does not. Or rather, if the early modern burden was shifted geographically, the later unburdening was geological. In addition, the fact that, even at this early date, temperate goods were more important than tropical imports in terms of the ghost acres that they represented, argues against unequal exchange and favours the specialization narrative.

All the land estimates considered so far concern only UK imports, on the implicit assumption that the land embedded in UK exports was negligible. However, this premature assumption is refuted by thorough estimates of land required for exported goods from the UK. Much of the imported cotton and wool, for example, was then re-exported in the form of textiles (see table 1 and figure 2). Theodoridis, Warde, and Kander estimated that almost two-thirds of the land embedded in raw cotton imports were then re-exported as cotton yarn and cotton goods throughout the nineteenth century, and by 1907 even more: 7.4-11.1 million acres of the 10-14 million acres of raw cotton imports were re-exported in the form of yarn and goods (not including their fossil acreage; see also table 2).

Similarly, just as raw wool was very land-intensive, so too were worsted and woollen textiles and yarn. For the first half of the nineteenth century, exports from these traditional UK textile industries exceeded those of raw wool imports, because they used raw wool domestically produced as well (see table 1). As late as 1870, exported woollen yarn and goods still totalled about half the acreage of raw wool imports. After this date, exports of woollen goods declined, although exports of yarn kept increasing, so that by 1907 the total remained at 10-20 million acres - by then only a sixth of raw wool imports (about 60-120 million acres) (see table 1). ${ }^{49}$

Theodoridis, Warde, and Kander's total for all land-based products show that UK net imports increased from 15-17 million acres in 1832, to 20-25 million acres in 1849, 40-60 million acres in 1870, and 130-190 million acres in 1907 (see table 1 and figure 2). So the UK did import more land-requiring products than it exported, just as the divergence narrative tells us to expect.

\footnotetext{
${ }^{46}$ Theodoridis, Warde, and Kander, 'Trade and overcoming'. On the ghost acreage of tallow, see J. Clifford, 'London's soap industry and the development of global ghost acres in the nineteenth century', Environment and History, forthcoming, https:// doi.org/10.3197/096734019X15463432086982 (consulted 17 February 2020).

${ }^{47} \mathrm{P}$. Warde, 'Trees, trade and textiles: potash imports and ecological dependency in British industry, c. 1550-1770', Past \& Present, 240, 2018, p. 76.

${ }^{48} \mathrm{M}$. Williams, Americans and their forests: an historical geography, New York: Cambridge University Press, 1989 , p. 139.

${ }^{49}$ Theodoridis, Warde, and Kander, 'Trade and overcoming'. None of these estimates take into account Wrigley's objection that wool was only part of the output, but treat the whole area as necessary for the woollen production. However, Theodoridis, Warde, and Kander consequently allocate no land to the by-products, such as mutton. This assumption can make sense from an individual country perspective, and for studying bilateral trade, but not if we want to apportion the entire global land area to different final production and consumption. Then double counting must be avoided: for instance, land used for both wool and meat must be distributed among those usages.
} 


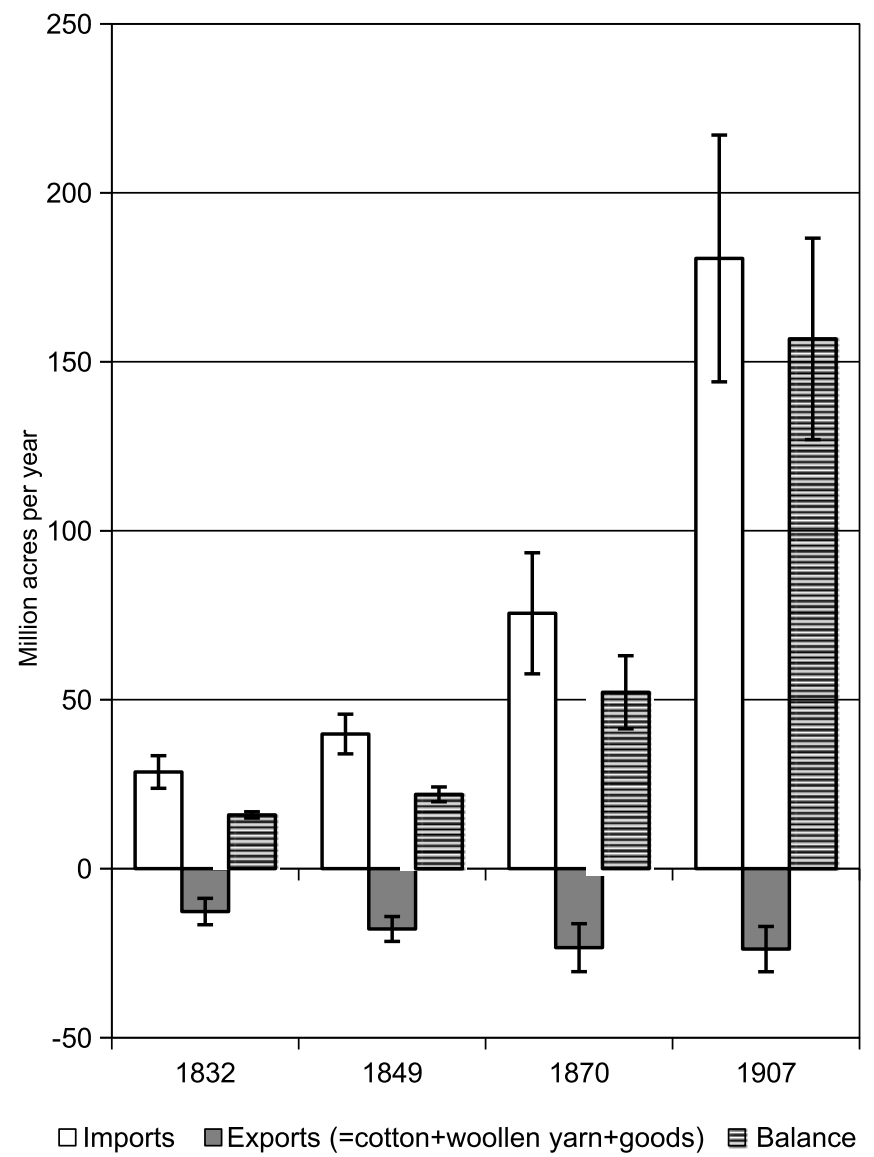

Figure 2. UK trade-embedded land, 1832-1907. Source: Theodoris, Warde, and Kander, 'Trade and overcoming'.

However, this is not strange from the perspective of specialization, given the UK's relatively high population density, which also suggests that it needed to import land.

However, the UK also exported coal, both directly and contained in energy-intensive goods. Thus, in line with the 'ecological footprint' and other consumption-based approaches, Theodoridis, Warde, and Kander also estimate the trade-embedded fossil acreage of actual coal and as embedded in goods, including coal itself, but especially textiles, pig iron, and iron and steel manufactures (see table 2).$^{50}$ Total net exports of fossil acreage increased from about 6-9 million acres in 1832, to 30-40 million acres in 1849, to 90-130 million acres in 1870, and 250-360 million acres in 1907 (see table 2 and figure 3). Whereas for most of the period embedded coal in British exported goods was responsible for two to three times as much as actual exported coal, by 1907 the situation was reversed. The UK's large exports of actual coal then helped fuel much of Europe's industrialization.

Including fossil acreage in the assessment and combining horizontal and vertical expansion, it turns out that the UK was a net exporter of land equivalents or 'ecological footprints' for all years except 1832 (see figure 3), which was before coal or coal-intense exports had begun to rise significantly, and then actually due to the vast land requirement (or land coefficient)

\footnotetext{
${ }^{50} \mathrm{Ibid}$. Coal is translated into corresponding wood equivalents using 3.5 tons of wood per ton of coal, and then into acres using $0.86-1.2$ tons of wood per acre.
} 
Table 2. Net exported coal acreage (million acres) in selected UK traded goods, 1832-1907

\begin{tabular}{lcccc}
\hline & 1832 & 1849 & 1870 & 1907 \\
\hline Cotton goods & $1.6-2.2$ & $4.4-6.2$ & $8.5-12.0$ & $12.5-17.6$ \\
Coal (actual + coal used in the & $1.9-2.7$ & $9.2-13.0$ & $37.3-52.6$ & $209.5-295.6$ \\
$\quad$ production of coal) & & & & \\
Pig iron & $0.2-0.3$ & $1.8-2.5$ & $6.3-8.9$ & $12.7-17.9$ \\
Iron and steel & $2.3-3.3$ & $11.0-15.5$ & $34.7-49.0$ & $24.8-35.0$ \\
Other metals & $0.6-0.9$ & $1.1-1.6$ & $8.5-12.1$ & $-1.0--1.4$ \\
Alkali soda & & $0.4-0.6$ & $2.4-3.4$ & \\
Sugar (refined) & & $-0.005-0.008$ & $-0.08--0.11$ & $-1.4--1.9$ \\
Woollen goods & & $1.5-2.1$ & $1.9-2.7$ & $1.1-1.5$ \\
Engines & & & $9.8-13.8$ \\
Total & $6.3-8.9$ & $28.0-39.5$ & $94.6-133.4$ & $254.5-359.0$ \\
\hline
\end{tabular}

Source: calculation based on Theodoridis, Warde, and Kander, 'Trade and overcoming', tables 1 and 6.

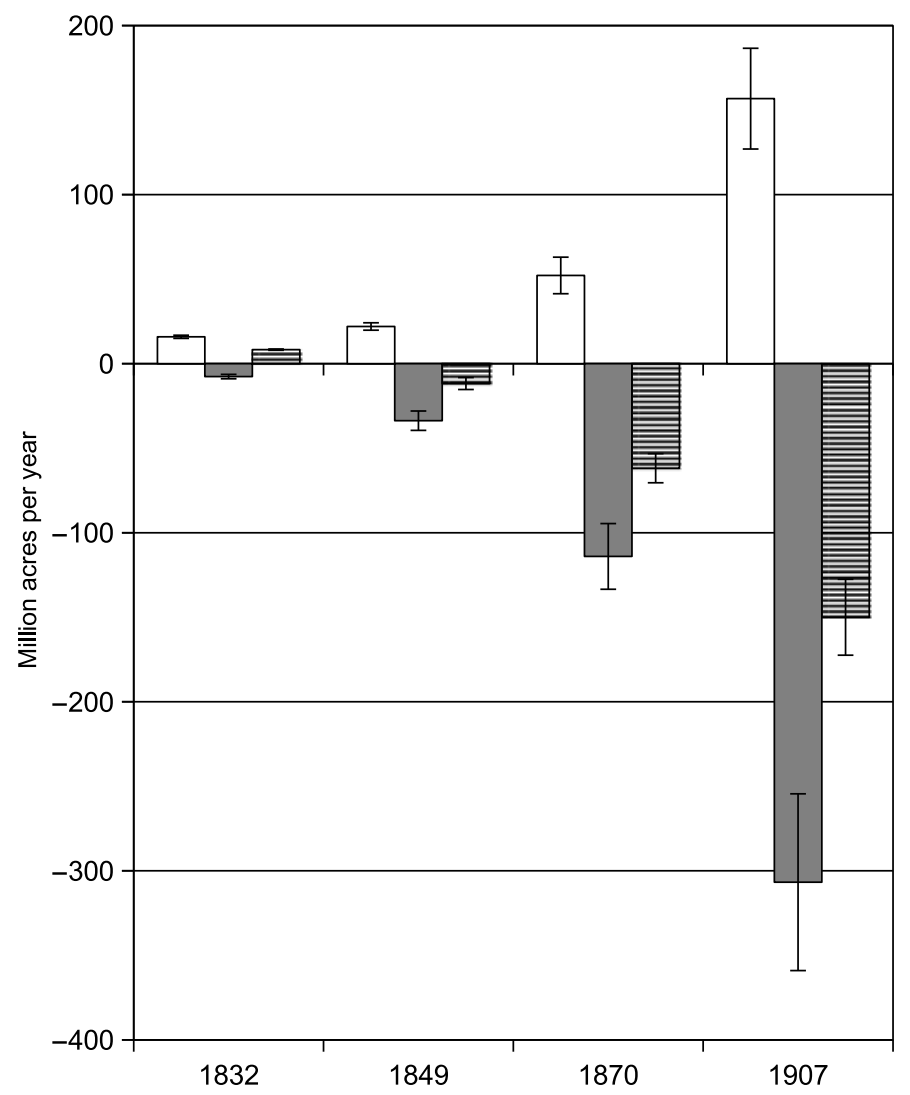

$\square$ Land $\square$ Fossils (direct+embedded) E Ecological footprint (land+fossils)

Figure 3. UK trade-embedded land, fossils, and ecological footprint, 1832-1907. Source: Theodoris, Warde, and Kander, 'Trade and overcoming'.

of imported potash rather than to the goods previously considered to be important, such as cotton, sugar, or timber.

In other words, if coal and the transition from an organic to a mineral economy was saving land within the UK, it was also, via trade, saving land overseas. As evidenced by its net exports, 
this external land saving was greater than the overseas lands indirectly used by the UK through imports. It remains an unanswered question whether these savings were limited to other industrializing nations without domestic coal supplies or whether they also included tropical countries.

\section{The role of coal in UK physical and embedded energy trade balance}

While trade-embedded land has been the principal preoccupation of historians, the first comprehensive factor-flow estimate was made within Austrian 'social ecology' by Schandl and Schulz for UK-traded materials between 1852 and $1997 .{ }^{51}$ The approach of this school, so-called 'material flow analysis', includes gathering information on the long-term physical trade balance (by weight), which is classified in groups of energy carriers, biomass, metallic, and non-metallic minerals. The studies on the UK also attempted to incorporate aspects of energy and land use, using biomass as a proxy for land. Their results in this respect suggest that the liberation from the land constraint in the metabolic transition to a fossil economy and freer trade did not result in diminished consumption of even domestic-land-dependent products, but rather took the form of alternative land use and increased biomass imports. Thus, in this perspective the possible environmental 'savings' from coal and trade-embedded acreage did not show up in absolute savings of domestic resources, but rather materialized as higher domestic consumption, somewhat in line with the narrative on divergence and displacement of environmental burdens.

Schandl and Schulz estimated the UK's physical trade balance since 1852. The annual averages in figure 4 show the generally rising trend for both imports and exports in material terms (in million tons). Contrary to the expectations from the narrative of ecologically unequal exchange, however, the century before 1950 was consistently characterized by net exports from Britain, and the trade shifted to net imports only after that. ${ }^{52}$

By 1913 the UK exported more than twice as much tonnage as was imported, exports constituting about a third and imports about a sixth of domestic material extraction. While biomass constituted more than $90 \%$ of imports until after the First World War, about equally distributed between edible and inedible, exports were entirely dominated by raw coal and comparatively small volumes of manufactures. Both imports and exports collapsed during the wars, but in the interwar period exports had a worse development than imports (see figure 4). This was almost entirely due to declining coal exports. However, it also reflected general trade difficulties, and the shifting of increasing volumes of manufactures into more advanced technical production, with higher value of products in relation to the physical weight, for instance electrical equipment. These trends continued into the post-war trade boom, when exports remained at lower absolute levels in 1950-1979, and imports, mostly of oil and other minerals, grew exponentially, yielding an average net import of 90 million tons. The take-off in exports since the 1980s was instead related to North Sea oil and gas exports, and in imports the take-off was due to a variety of products. ${ }^{53}$

Thus, over the whole 150-year period, the UK turned from being a net exporter before 1950 to a net importer after that. This change was characterized by net imports of biomass and minerals,

\footnotetext{
${ }^{51}$ H. Schandl and N. Schulz, 'Changes in the United Kingdom's natural relations in terms of society's metabolism and land use from 1850 to the present day', Ecological Economics, 41, 2002, pp. 203-21. This study is also the basis for the UK figures in F. Krausmann, H. Schandl, and N. B. Schulz, 'Long-term industrial transformation: a comparative study on the development of social metabolism and land use in Austria and the United Kingdom 1830-2000', Social Ecology Working Paper 70, IFF, Vienna, 2003; R. P. Sieferle, F. Krausmann, H. Schandl, and V. Winiwarter, Das Ende der Fläche: zum sozialen Metabolismus der Industrialisierung, Cologne: Böhlau, 2006; and S. Gingrich, 'Foreign trade and early industrialisation in the Habsburg monarchy and the United Kingdom: two extremes in comparison', Ecological Economics, 70, 2011, pp. 1280-8.

${ }^{52}$ Schandl and Schulz, 'Changes'.

${ }^{53}$ Ibid.
} 


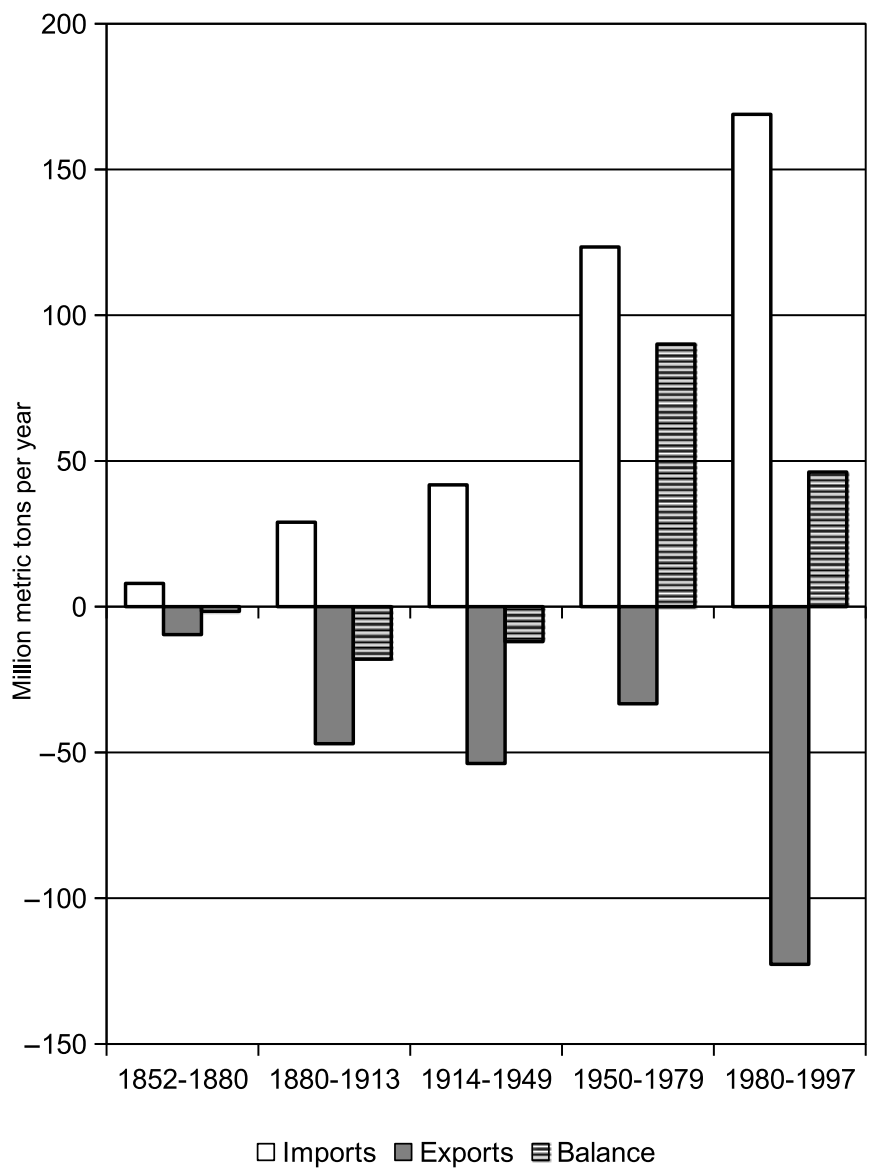

Figure 4. UK physical trade balance, 1852-1997. Source: Schandl and Schulz, 'Changes in the United Kingdom'.

and dramatic swings of traded fossil fuels, from net exports of coal to large net imports of oil, and then a balanced trade of oil. ${ }^{54}$

This picture is consistent with the perspective from specialization according to endowments, and contradicts the argument about an ecologically unequal exchange in physical terms before 1950. Gingrich further notes that, since the UK monetary foreign trade balance was negative from 1860 to 1910 , despite the fact that many more materials were exported than imported, the price of exported materials was much lower than that of imports. In short, the large volumes of cheap coal did not fully compensate for the smaller volume of high-priced biomass. ${ }^{55}$ The 'great acceleration' narrative can draw some support from the large expansion of trade after the Second World War. However, as pointed out by Gingrich, the physical weights and volumes of UK exports in the early twentieth century exceeded by far anything reached until the late $1970 s^{56}$ In fact, even net exports of the early twentieth century are comparable to net imports of the late twentieth century. ${ }^{57}$

Turning from direct trade in energy carriers such as coal and oil to the energy required to produce goods, and thus indirectly embedded in trade, Kander et al. present energy accounts from

\footnotetext{
${ }^{54}$ Ibid.

${ }^{55}$ Gingrich, 'Foreign trade'.

${ }^{56}$ Ibid.

${ }^{57}$ Schandl and Schulz, 'Changes'.
} 


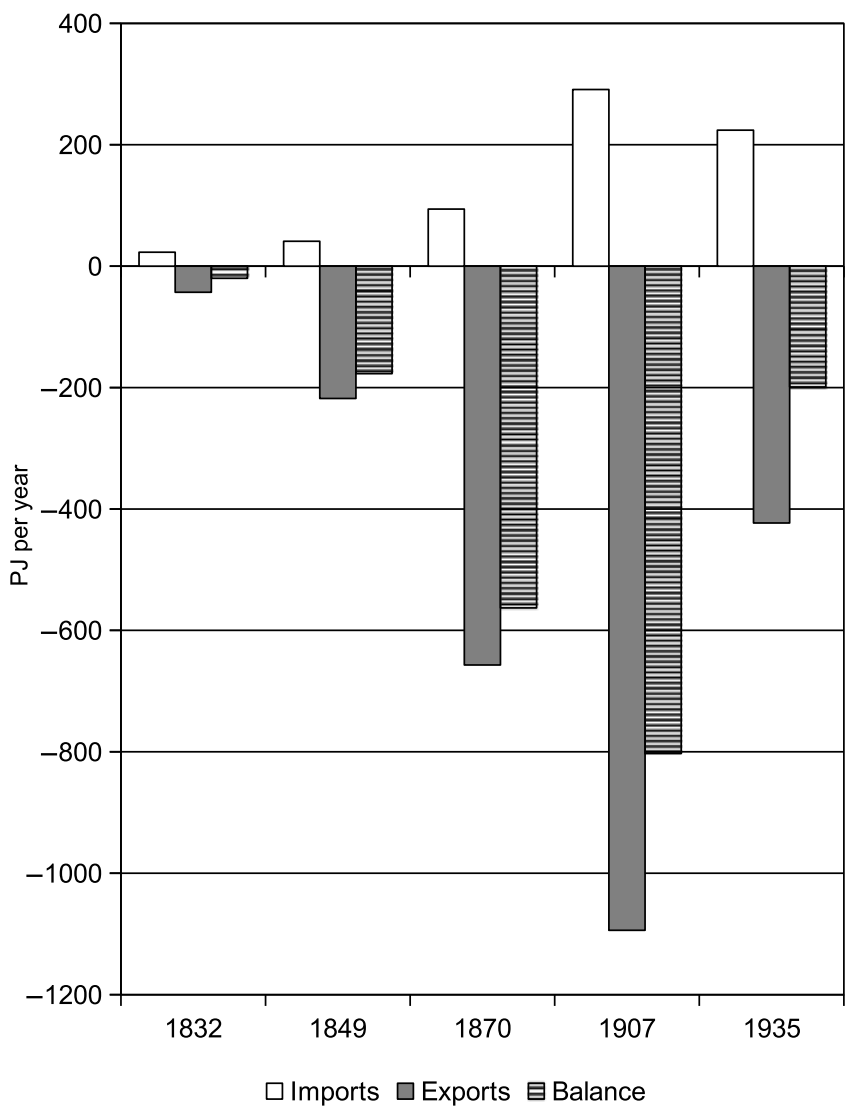

Figure 5. UK trade-embedded energy, 1832-1935. Source: Kander et al., 'International trade'.

both the production and the consumption side for the UK for the century between 1832 and $1935 .{ }^{58}$ If Schandl and Schulz document the UK's great exports of direct energy (raw coal and coke), Kander et al. show that the UK also exported much more indirect energy than was imported (see figure 5). The trend is remarkably similar to that for material flows, and, although both depend on coal, they do so for entirely different reasons. Thus, the production-based energy account has already subtracted net flows of traded energy carriers such as coal and oil in physical terms, so that what this embedded energy estimate shows is the energy required to produce the traded goods (whether coal, biomass, or manufactured goods such as textiles or iron). While it includes the energy used up in the extraction and transportation of coal (and other goods), it does not include the energy contained within exported coal (or firewood or oil), because that is already included in production-based accounts of energy histories. On both accounts - direct energy and indirect energy requirements of commodities - the UK emerges as being a substantial net exporter of energy until the Second World War.

This is not in line with the 'great divergence' narrative, and it directly contradicts ecologically unequal exchange as expressed in energy. ${ }^{59}$ However, since the UK can be considered to be well endowed with coal (and the know-how and institutions for mining it), it conforms very well

\footnotetext{
${ }^{58}$ A. Kander, P. Warde, S. T. Henriques, H. Nielsen, V. Kulionis, and S. Hagen, 'International trade and energy intensity during European industrialization, 1870-1935', Ecological Economics, 139, 2017, pp. 33-44. See also P. Warde, 'Energy embodied in traded goods for the United Kingdom, 1870-1935: discussion of methods and sources', 2016, https://histecon.fas.harvard. edu/energyhistory/British_energy_multipliers_Warde_Nov_2016.pdf (consulted 3 October 2018).

${ }^{59}$ Bunker, 'Modes of extraction'; Bunker, Underdeveloping the Amazon; Hornborg, 'Towards an ecological theory'.
} 
with comparative advantage, in that there is specialization in the production and export of energyintensive products.

\section{Long-term studies of other regions' environmental factors in trade}

The reverse side of early English imports of potash are their exports from the Baltic, which are included in a study of Swedish 'emergy' in exported forest products, c.1640-50. ${ }^{60}$ Far from being seen as detrimental, they were used rather to 'explain' the rise of Sweden as a superpower between 1611 and $1718 .^{61}$

The oil crises of the 1970s and later global warming stimulated new Swedish energy studies. Certain benchmarks in 1955-2000 were established to determine if the embedded energy trade balance (namely, increasing net imports) could explain the fact that GDP had increased much faster than energy consumption since $1970 .^{62}$ In a similar vein, but more ambitiously, a Swedish input-output study by Lindmark was extended to embedded carbon dioxide for the period 1913-95. ${ }^{63}$ These studies found that Swedish declines in energy consumption and carbon dioxide emissions in relation to GDP (relative decoupling) were not at all explained by foreign trade, but driven by technical change and changed consumption patterns.

With a similar focus on long-term national trends in energy use in relation to GDP, ${ }^{64}$ estimates of both direct and embedded energy in trade have been expanded temporally and geographically to include Germany, Italy, Sweden, Denmark, and Portugal, for benchmarks in the period 1870-1935, as well as the Czech lands for 1849-1935, and the UK for $1832-1935 .^{65}$ In line with the specialization narrative, countries with energy-intense export industries based on either domestic coal (UK, Germany, the Czech lands), or charcoal and imported coal (Sweden), were also net exporters, while all the other countries were net importers. ${ }^{66}$ The share of exported to total energy peaked in 1870 or 1913 for most countries at $19-27 \%$,

\footnotetext{
${ }^{60} \mathrm{An}$ 'emergy' analysis basically adds up all the energy required to produce a good through all steps of production back to its origin in solar inflow, which is one step further upstream than conventional input-output studies.

${ }^{61}$ H. T. Odum, U. Sundberg, J. Lindegren, and S. Doherty, 'Forest emergy basis for Swedish power in the 17th century', Scandinavian Journal of Forest Research, supplement 1, 1994; U. Sundberg, J. Lindegren, H. T. Odum, S. Doherty, and H. Steinlin, 'Skogens användning och roll under det svenska stormaktsväldet: perspektiv på energi och makt (The use and role of the forest during the Swedish empire: perspectives on energy and power)', SOLMED, 8, 1995, available at https://www.ksla. se/wp-content/uploads/2019/05/SOLMED-nr-8-Skogens-användning-och-roll-under-det-svenska-stormaktsväldet.pdf (consulted 17 February 2020). See also Warde, 'Trees, trade and textiles'. For eighteenth-century Swedish-Chinese exchange of iron and tea expressed as 'land', see R. Warlenius, 'Core and periphery in the early modern world system: a time-space appropriation assessment', in A. Jarrick, J. Myrdal, and M. Wallenberg Bondesson, eds., Methods in world history: a critical approach, Lund: Nordic Academic Press, 2016.

${ }^{62}$ A. Kander, Economic growth, energy consumption and $\mathrm{CO}_{2}$ emissions in Sweden 1800-2000, Lund Studies in Economic History 19, Lund: Almqvist \& Wiksell International, 2002.

${ }^{63}$ M. Lindmark, 'Koldioxideffektivitet i ekonomisk-historiskt perspektiv (Carbon dioxide efficiency from an economic history perspective)', Occasional Papers in Economic History 5, Department of Economic History, Umeå University, 2001; A. Kander and M. Lindmark, 'Foreign trade and declining pollution in Sweden: a decomposition analysis of long-term structural and technological effects', Energy Policy, 34, 2006, pp. 1590-9.

${ }^{64}$ A. Kander, P. Malanima, and P. Warde, Power to the people: energy in Europe over the last five centuries, Princeton, NJ: Princeton University Press 2013; see also P. Malanima, Energy consumption in Italy in the 19th and 20th centuries: a statistical outline, Naples: Consiglio Nazionale delle Ricerche, Istituto di Studi sulle Società del Mediterraneo, 2006; P. Warde, Energy consumption in England and Wales, 1560-2000, Naples: Consiglio Nazionale delle Ricerche Istituto di Studi sulle Società del Mediterraneo, 2007.

${ }^{65}$ Kander et al., 'International trade'.

${ }^{66} \mathrm{Ibid}$. See also the argument on 'developmental blocks' in Kander, Malanima, and Warde, Power to the people. Believing that net energy exports were detrimental, R. N. Adams, Paradoxical harvest: energy and explanation in Great Britain, 1870-1914, Cambridge: Cambridge University Press, 1982, argued that this was what caused the relative 'decline' of late nineteenth-century UK, but this is contradicted by the other net exporters, Germany, the Czech lands, and Sweden; see also Japan's exports of coal until the 1920s (figure 7), and the US net exports of 'emergy' for about a century after 1865 (decipherable from D. R. Tilley, 'National metabolism and communications technology development in the United States, 1790-2000', Environment and History, 12, 2006, fig. 5c).
} 
but with Italy and Portugal far behind at 4-5\%. Import shares were almost the reverse, with coal rich countries at 3-5\%, most others (including Germany in 1872) peaking at $17-23 \%$, and Denmark standing out at $48 \% .^{67}$

The Danish case nuances the facile connection between energy-intense exports and a large supply and use of coal and charcoal. Being short both of domestic coal and wood resources, Denmark was a net importer of actual and embedded energy. Nevertheless, Danish exports of agricultural goods (butter and pork) to the UK had become very energy-intensive by 1913, based on large direct and indirect (in the form of fertilizers and feed) energy imports. Thus, even in this early globalization from 1870, trade and energy cannot be fully grasped only in terms of bilateral links, but must be understood in a multilateral context. ${ }^{68}$

In spite of the US's long track record in energy historiography, the generalization that a large supply and use of domestic energy sources coincided with net energy exports has so far not been tested. Since the US was well supplied with both fossil fuels and forests to produce charcoal, this implies that it should have been a net exporter of trade-embedded energy. However, its position as a largely agricultural periphery to the UK might suggest a different story, or possibly a shift over time. The only study we have managed to identify for this review is Tilley's estimate of US trade-embedded 'emergy'. US foreign trade appears balanced in 'emergy' terms until the final third of the nineteenth century, after which it turned into a net exporter for about a century, and shifted to a net importer only in the final decades of the twentieth century. These trends are not analysed by Tilley, but evidently correspond to the monetary trade balance. ${ }^{69}$

The 1960s saw an early wave of studies on the natural resource content of US trade, which are among the main sources for newer material flow analyses. ${ }^{70}$ According to these (see figure 6 ), the US was a net exporter until just after the Second World War, first due to large net exports of biomass, and then increasingly due to exports of fossil fuels. Interestingly, the US turned into a net importer of biomass from the 1920s until 1960, which also corresponds to the period in which the country's 'insatiable appetite' for tropical goods is best documented. However, this was most notably because of stagnating or decreasing exports during the dust bowl years, rather than merely reflecting increased imports. ${ }^{71}$ After the Second World War, booming imports of fossil fuels (and other minerals) turned the US into a net importer, reflecting both the energy transition from coal to oil, and the increasing dependence on Middle Eastern oil. ${ }^{72}$

Contrary to widespread neo-Malthusian expectations, Barnett and Morse appeared to show that the US had not become more resource-scarce between 1870 and 1957, in spite of its growing economy and extraction of resources. ${ }^{73}$ Contributing to this debate, Vanek estimated the direct and indirect natural resource content of US trade, showing that the US acted primarily as a net

\footnotetext{
${ }^{67}$ Kander et al., 'International trade'.

${ }^{68} \mathrm{~S}$. T. Henriques and P. Warde, 'Fuelling the English breakfast: hidden energy flows in the Anglo-Danish trade, 1870-1913', Regional Environmental Change, 18, 2018, pp. 965-77.

${ }^{69}$ Tilley, 'National metabolism', pp. 175, 178. Tilley's calculation is based on the balance of trade in monetary terms and an 'emergy' per dollar ratio, which is derived by dividing total annual US 'emergy' use by GDP, and is assumed to be the same for imports and exports.

${ }^{70} \mathrm{~N}$. Potter and F. T. Christy, Trends in natural resource commodities: statistics of prices, output, consumption, foreign trade, and employment in the United States 1870-1957, Baltimore, MD: Johns Hopkins University Press, 1962; R. S. Manthy, Natural resource commodities: a century of statistics: prices, output, consumption, foreign trade and employment in the United States, 1870-1973, Baltimore, MD: Johns Hopkins University Press, 1978; S. Gierlinger, 'Die langfristigen Trends der Material- und Energieflüsse in den USA in den Jahren 1850 bis 2005', Social Ecology Working Paper 128, IFF Vienna, 2010; S. Gierlinger and F. Krausmann, 'The physical economy of the United States of America: extraction, trade and consumption of materials from 1870 to 2005', Journal of Industrial Ecology, 16, 3, 2012, pp. 365-77.

${ }^{71}$ Tucker, Insatiable appetite; Gierlinger and Krausmann, 'Physical economy', supplementary information.

${ }^{72}$ Gierlinger and Krausmann, 'Physical economy', pp. 369, 371; Gierlinger, 'Die langfristigen Trends'.

${ }^{73} \mathrm{H}$. J. Barnett and C. Morse, Scarcity and growth: the economics of natural resources, Baltimore, MD: Johns Hopkins University Press, 1963. See also P. A. David and G. Wright, 'Increasing returns and the genesis of American resource abundance', Industrial and Corporate Change, 6, 2, 1997, pp. 203-45.
} 
USA, 1870-2005
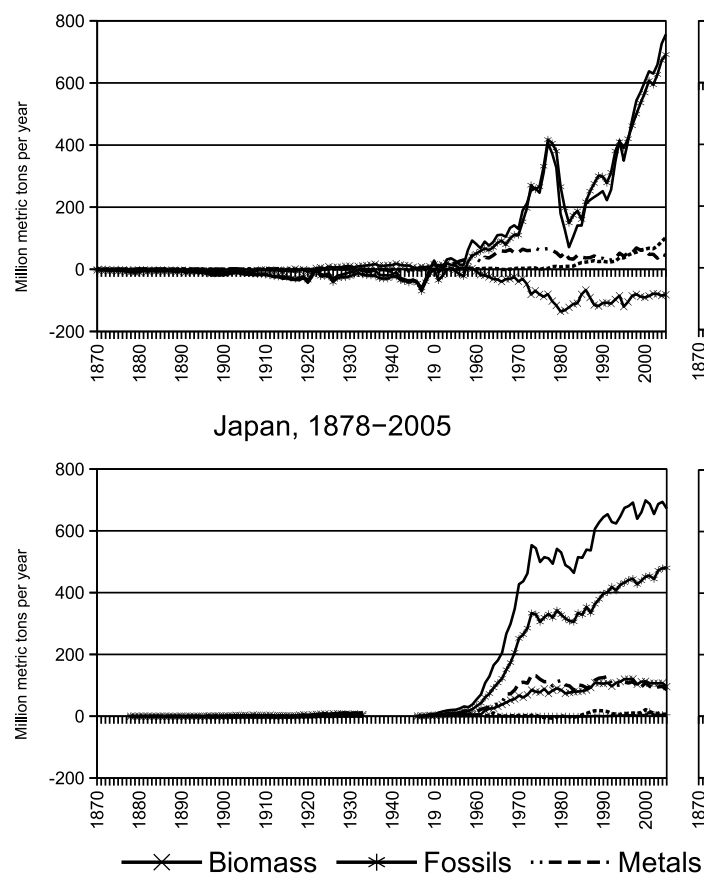

Russia/USSR, 1870-2008

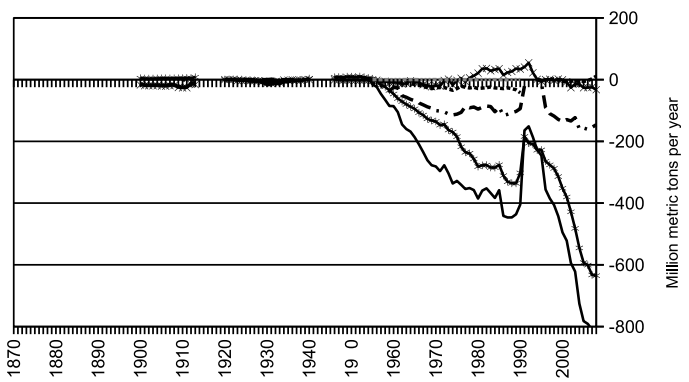

India, 1961-2008

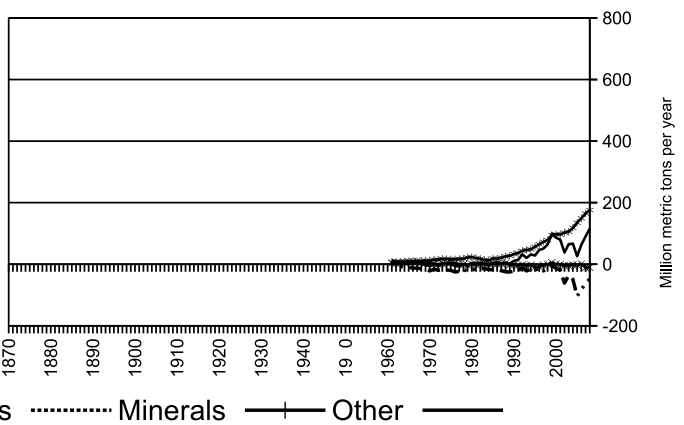

Figure 6. Physical trade balance (PTB) of the USA, Russia/USSR, Japan, and India, 1870-2008. Negative values denote net exports. Sources: Gierlinger and Krausmann, 'Physical economy'; Krausmann et al., 'Metabolic transition of a planned economy'; Krausmann, Gingrich, and Nourbakhch-Sabet, 'Metabolic transition of Japan'; Singh et al., 'India's biophysical economy'.

exporter of natural resources in 1870, but with a declining trend, so that from the early 1920s the US turned into a net importer. In a very modern-sounding argument, he thus suggested that the Malthusians might yet be correct and that the US could have transferred its scarcity abroad through trade. ${ }^{74}$ Allen similarly documents the declining share of primary products in US exports, from $80 \%$ in $1820-1895$, to $50 \%$ around 1920 , and to $10 \%$ by the late twentieth century. But rather than pointing to the redistribution of environmental burdens, he concludes that surging US productivity shifted the country's 'comparative advantage' from agriculture to manufacturing after $1895 .^{75}$ This interpretation corresponds well with the shift away from exports of biomass in physical terms over the same period (see figure 7), although these figures imply that the US's inherent comparative advantage in agriculture reasserted itself after the Second World War (see figure 6).

The most prolific tradition is probably Austrian social ecology, which has generated numerous long-term national estimates of the physical trade balance. The data on the UK was used in comparisons with the Habsburg empire and its Austrian and Czech regions and successor states. ${ }^{76}$ The external trade of the Habsburg empire was very small compared with that of the UK, strengthening the case for the unimportance of early trade-embedded transfers. Imports and exports,

\footnotetext{
${ }^{74} \mathrm{~J}$. Vanek, 'The natural resource content of foreign trade, 1870-1955, and the relative abundance of natural resources in the United States', Review of Economics and Statistics, 41, 2, part 1, 1959, pp. 146-53; J. Vanek, The natural resource content of United States foreign trade 1870-1955, Cambridge, MA: MIT Press, 1963.

${ }^{75}$ R. C. Allen, 'American exceptionalism as a problem in global history', Journal of Economic History, 74, 2, 2014 , p. 311.

${ }^{76}$ Krausmann, Schandl, and Schulz, 'Long-term industrial transformation'; Sieferle et al., Ende der Fläche; Gingrich, 'Foreign trade'.
} 
USA, $1870-1950$

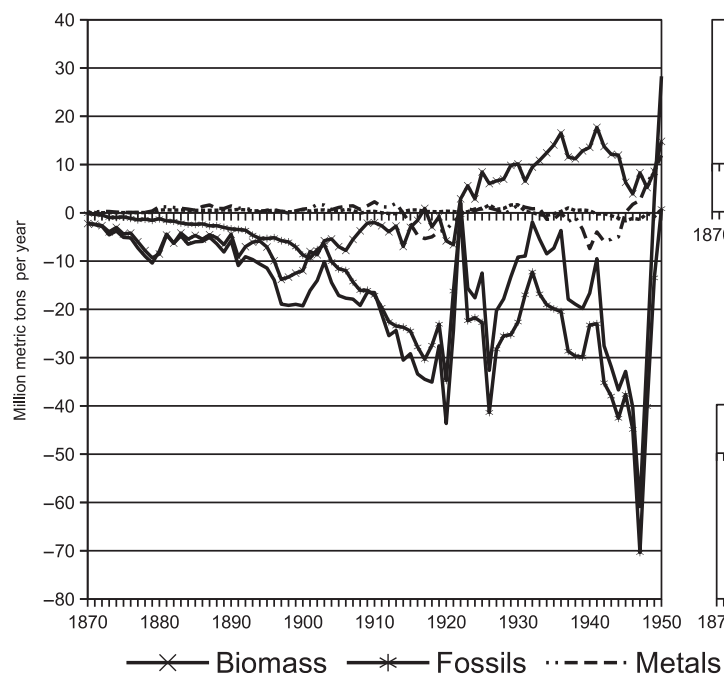

Japan, 1878-1950

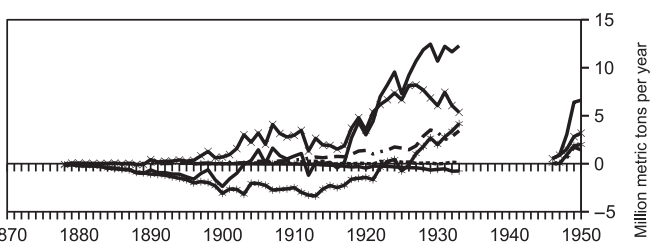

Russia/USSR, 1900-1950

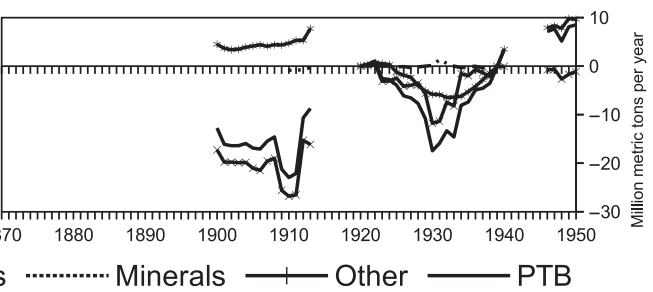

Figure 7. Physical trade balance (PTB) of the USA, Russia/USSR, and Japan before 1950. Negative values denote net exports. Sources: Gierlinger and Krausmann, 'Physical economy'; Krausmann et al., 'Metabolic transition of a planned economy'; Krausmann, Gingrich, and Nourbakhch-Sabet, 'Metabolic transition of Japan'.

totalling about 20 million tons each by 1913 (compared with 50 and 100 million tons respectively for the UK), were both dominated by coal followed by biomass. However, the fact that the Habsburg empire was land-locked and twice as large as the UK, at a time when land trade was still very expensive, also makes it something of an outlier. ${ }^{77}$

Interregional trade within the empire, which after 1918 turned international, again shows the importance of energy carriers. Krausmann and Haberl provided estimates for Austrian biomass and fossil fuels since 1874 (import data only of fossil fuels until the interwar period), while Erb et al. studied trade-embedded carbon since $1830 .^{78}$ Kuskova, Gingrich, and Krausmann estimated the direct energy flows (for example, for coal) for the Czech lands of the Habsburg empire and Czechoslovakia since 1852, and Kovanda and Hak the physical trade balance since 1855, which was much dominated by increasing coal exports until the interwar period. It shifted to net imports only with increasing oil imports in the post-war period, in spite of continued large exports of coal. ${ }^{79}$ The trade-embedded (indirect) energy flows, studied since 1849, also show net exports from the start, but in this case they continued into the planned economy period, peaking only in 1972, based on energy-intense steel and machinery exports. $^{80}$

\footnotetext{
${ }^{77}$ Gingrich, 'Foreign trade'.

${ }^{78} \mathrm{~F}$. Krausmann and H. Haberl, 'The process of industrialization from the perspective of energetic metabolism socioeconomic energy flows in Austria 1830-1995', Ecological Economics, 41, 2002, pp. 177-201; K.-H. Erb, S. Gingrich, F. Krausmann, and H. Haberl, 'Industrialization, fossil fuels and the transformation of land use: an integrated analysis of carbon flows in Austria 1830-2000', Journal of Industrial Ecology, 12, 5-6, 2008, pp. 686-703.

${ }^{79} \mathrm{P}$. Kuskova, S. Gingrich, and F. Krausmann, 'Long term changes in social metabolism and land use in Czechoslovakia, 1830-2000: an energy transition under changing political regimes', Ecological Economics, 68, 2008, pp. 394-407; J. Kovanda and T. Hak, 'Historical perspectives of material use in Czechoslovakia in 1855-2007', Ecological Indicators, 11, 2011, p. 1378.

${ }^{80}$ Kander et al., 'International trade'; H. Nielsen, Coal, commerce and communism: empirical studies on energy history in the Czech Republic, Lund: Media-Tryck, 2017; H. Nielsen, 'Industrial intensification and energy embodied in trade: longrun energy perspective of the planned economy of Czechoslovakia', Journal of Industrial Ecology, 22, 6, 2018, pp. 1436-50.
} 
Moving in ever wider geographical circles, there are now trade-informed material flow analyses of Russia, and then the USSR, since 1900, Spain since 1860, the US since 1870, Japan since 1878, and many other regions (such as India) from 1961 onwards (see figure 6). ${ }^{81}$ In addition, a few other studies contain long-term estimates of biomass flows: for example for Italy since 1884, and the Philippines since $1910 .^{82}$ However, most, such as those for Germany, contain trade information only since 1961, or only in monetary terms. ${ }^{83}$ In addition, as the world's second largest importer of wood, Germany's wood acreage from central Europe has been estimated at 17.8 million acres by 1907/13, largely explaining how domestic forests could expand over the preceding four decades. ${ }^{84}$

In line with the 'great acceleration' narrative, these analyses show such large increases in the post-war period that previous flows are barely visible. The share of US exports and imports to domestic extraction was only $2 \%$ and $0.2 \%$ respectively in 1913, compared with $5 \%$ and $15 \%$ in 2005. Japanese shares were $5 \%$ for both exports and imports in 1913 , but $15 \%$ and $80 \%$ in 2005. In line with the 'specialization' narrative, the large and resource-abundant Russia/USSR was a net exporter, while resource-scarce countries were net importers. Thus, both richer, smaller, and crowded Japan and poorer, larger, and crowded India are net importers. Zooming in on flows before 1950 (see figure 7), while imperial Japan imported biomass and metal ores, the nation was a net exporter of fossil fuels. And while Tsarist Russia exported biomass, it imported fossil fuels, a situation that contrasted markedly with the final decades of the USSR (see figure 6), reflecting both the crisis of agriculture and the low esteem in which it was held by Soviet authorities. The great 'grain invasion' of the late nineteenth century has recently been framed as an 'unequal exchange' of grain between a net-importing European centre and net-exporting US and Russian semi-peripheries from 1850 onwards (see figure 7), ${ }^{85}$ although this event was also what inspired the theory of specialization according to endowments. ${ }^{86}$

\footnotetext{
${ }^{81}$ F. Krausmann, B. Gaugl, J. West, and H. Schandl, 'The metabolic transition of a planned economy: material flows in the USSR and the Russian Federation 1900 to 2010', Ecological Economics, 124, 2016, pp. 76-85; J. Infante-Amate, D. Soto, E. Aguilera, R. García-Ruiz, G. Guzmán, A. Cid, and M. González de Molina, 'The Spanish transition to industrial metabolism: long-term material flow analysis (1860-2010)', Journal of Industrial Ecology, 19, 5, 2015, pp. 866-76; Gierlinger and Krausmann, 'Physical economy'; Gierlinger, 'Die langfristigen Trends'; F. Krausmann, S. Gingrich, and R. NourbakhchSabet, 'The metabolic transition in Japan: a material flow account for the period 1878 to 2005', Journal of Industrial Ecology, 15, 6, 2011, pp. 877-92; S. J. Singh, F. Krausmann, S. Gingrich, H. Haberl, K.-H. Erb, P. Lanz, J. Martinez-Alier, and L. Temper, 'India's biophysical economy, 1961-2008: sustainability in a national and global context', Ecological Economics, 76, 2012, pp. 60-9.

${ }^{82} \mathrm{M}$. Niedertscheider and K.-H. Erb, 'Land system change in Italy from 1884 to 2007: analysing the north-south divergence on the basis of an integrated indicator framework', Land Use Policy, 39, 2014, pp. 366-75; T. Kastner, 2009, 'Trajectories in human domination of ecosystems: human appropriation of net primary production in the Philippines during the 20th century', Ecological Economics, 69, 2009, pp. 260-9.

${ }^{83}$ Since 1961, see, for example, M. Niedertscheider, T. Kuemmerle, D. Müller, and K.-H. Erb, 'Exploring the effects of drastic institutional and socio-economic changes on land system dynamics in Germany between 1883 and 2007', Global Environmental Change, 28, 2014, pp. 98-108; P. de Souza and Y. Malhi, 'Land use change in India (1700-2000) as examined through the lens of human appropriation of net primary productivity', Journal of Industrial Ecology, 22, 5, 2018, pp. 1202-12. In monetary terms, see, for example, T. Fetzel, M. Gradwohl, and K.-H. Erb, 'Conversion, intensification, and abandonment: a human appropriation of net primary production approach to analyze historic land-use dynamics in New Zealand 1860-2005', Ecological Economics, 97, 2014, pp. 201-8.

${ }^{84}$ J. Daheur, 'La sylviculture allemande et ses “hectares fantômes" au tournant des XIXe et XXe siècles', Revue forestière française, 3, 2017, pp. 227-39.

${ }^{85} \mathrm{~F}$. Krausmann and E. Langthaler, 'Nahrungsregime und Umwelt in der Globalisierung (1870-2010)', in K. Fischer, J. Jäger, and L. Schmidt, eds., Rohstoffe und Entwicklung: aktuelle Auseinandersetzungen im historischen Kontext, Vienna: New Academic Press, 2016, pp. 85-106.

${ }^{86} \mathrm{E}$. F. Heckscher, 'Utrikeshandelns verkan på inkomstfördelningen: några teoretiska grundlinjer (The effect of foreign trade on the distribution of income: some theoretical baselines)', Ekonomisk tidskrift (Journal of Economics), 21 (part II), 1919, pp. 1-31; K. H. O’Rourke, 'The European grain invasion, 1870-1913', Journal of Economic History, 57, 1997, pp. $775-801$.
} 
Studies of Spain's material flows centre on biomass as a diminishing share in total material flows, and the corresponding transition to fossil fuels. Spain was a net exporter until 1930, and turned into a net importer after $1960{ }^{87}$ Studies of the Spanish wood trade also go back to 1860. A recurrent finding is that the industrial transition shifted the uses made of wood and biomass but did not result in decreased use in absolute terms. ${ }^{88}$ This argues against the idea of absolute environmental savings from trade, and speaks in favour of another narrative in environmental history: the rebound effect, or take-back effect, introduced by Stanley Jevons in 1865 to explain why the use of coal would not diminish when more efficient machines were invented and introduced. ${ }^{89}$ As the energy services become cheaper, they would be used more. When fossil fuels were introduced to save wood, the relative price of wood fell, and other uses could be found for it, such as producing paper. In contrast, the work by Duarte, Pinilla, and Serrano on 'virtual water' (that is, water used in the production of, and exchanged in the form of, agricultural goods) in 1849-1935 and 1965-2010 argues that trade alleviated pressures on domestic water resources compared with what would have been needed without it. Thus, contrary to what might have been expected, based on biomass flows alone, but in accordance with what would be expected from its dry climate (and the specialization narrative), Spain was mostly a net importer of virtual water after about $1900 .^{90}$

\section{Are exports from peripheral countries evidence of unequal exchange?}

If long-term national studies are almost exclusively on developed countries, environmental and world-system historians have a penchant for exports from peripheral or less-developed countries. ${ }^{91}$ Studies of these ecological 'teleconnections' of industrialization ${ }^{92}$ are almost by definition within the 'divergence' narrative. The studied exports include Central American bananas and silver, Cuban sugar, Brazilian rubber and coffee, Argentine quebracho, Indian or Philippine timber and plantation crops, Southeast Asian gutta-percha and tin, East African ivory, Namibian

\footnotetext{
${ }^{87}$ Infante-Amate et al., 'Spanish transition'.

${ }^{88}$ I. Iriarte-Goñi, 'Forests, fuelwood, pulpwood, and lumber in Spain, 1860-2000: a non-declensionist story', Environmental History, 18, 2, 2013, pp. 333-59; I. Iriarte-Goñi and M.-I. Ayuda, 'Protección e importaciones de madera en España (1880-1935)', Investigaciones de Historia Economica, 9, 2007, pp. 45-78; I. Iriarte-Goñi and M.-I. Ayuda, 'Wood and industrialization: evidence and hypotheses from the case of Spain, 1860-1935', Ecological Economics, 65, 2008, pp. 177-86; Iriarte-Goñi and Ayuda, 'Not only subterranean forests'.

${ }^{89} \mathrm{~W}$. S. Jevons, The coal question: an inquiry concerning the progress of the nation and the probable exhaustion of our coalmines, London: Macmillan and Co, 1865, pp. 103-4.

${ }^{90}$ R. Duarte, V. Pinilla, and A. Serrano, 'The effect of globalisation on water consumption: a case study of the Spanish virtual water trade, 1849-1935', Ecological Economics, 100, 2014, pp. 96-105; R. Duarte, V. Pinilla, and A. Serrano, 'Globalization and natural resources: the expansion of the Spanish agrifood trade and its impact on water consumption, 1965-2010', Regional Environmental Change, 16, 2016, pp. 259-72. This approach has also been applied to ancient Rome by B. J. Dermody, R. P. H. van Beek, E. Meeks, K. Klein Goldewijk, W. Scheidel, Y. van der Velde, M. F. P. Bierkens, M. J. Wassen, and S. C. Dekker, 'A virtual water network of the Roman world', Hydrology and Earth System Science, 18, 2014, pp. 5025-40.

${ }^{91}$ There is a striking discrepancy between the secular to millennial horizon of world-system approaches and quantitative estimates of ecologically unequal exchange which normally only cover the period after 1970. See S. J. Singh and N. Eisenmenger, 'How unequal is international trade? An ecological perspective using material flow accounting (MFA)', Journal für Entwicklungspolitik, 26, 2011, pp. 57-88. Hornborg, 'Footprints', is the partial exception that proves this rule, studying only one-way resource flows. Narrative studies of commodity chains/frontiers, and unequal exchange include A. A. Quark, 'Toward a new theory of change: socio-natural regimes and the historical development of the textiles commodity chain', Review (Fernand Braudel Center), 31, 1, 2008, pp. 1-37; M. Evenden, 'Aluminum, commodity chains, and the environmental history of the Second World War', Environmental History, 16, 2011, pp. 69-93; Moore, 'Modern worldsystem'; B. Clark and J. B. Foster, 'Ecological imperialism and the global metabolic rift: unequal exchange and the guano/ nitrates trade', International Journal of Comparative Sociology, 50, 3-4, 2009, pp. 311-34; Bunker, 'Modes of extraction'; Bunker, Underdeveloping the Amazon.

${ }^{92}$ J. R. McNeill, 'Cheap energy and ecological teleconnections of the Industrial Revolution, 1780-1920', Environmental History, 24, 2019, pp. 492-503.
} 
cattle, and New Zealand wool, meat, and seed grass. ${ }^{93}$ Although occasionally time-series of exports of individual commodities can be found, ${ }^{94}$ these studies tend to be narrative rather than quantitative, and by their nature rarely aim for full coverage of all goods. A few narrative syntheses of US and imperial environmental impact on tropical and subtropical lands in the centuries before 1950 cover commodities such as sugar, furs, wool, meat, cotton, cocoa, coffee, bananas, rubber, tin, copper, oil, and timber. ${ }^{95}$ The most comprehensive collection of land intensity coefficients for much of the globe in the nineteenth and early twentieth centuries currently covers about eighty commodities. $^{96}$

Unfortunately, by excluding flows in the opposite direction (from developed centres to less-developed peripheries) - for example, of food, textiles, coal, ${ }^{97}$ iron and steel products - these studies cannot address the problem of whether trade-embedded environmental factors contributed to 'divergence' and 'unequal exchange', or to environmental savings through 'comparative advantage', or whether they did both, or neither, of these things. ${ }^{98}$ In other words, while seemingly adopting a 'consumption-based' perspective by looking at the environmental effects of developed country consumption in tropical or less-developed regions, these studies fail to answer whether

\footnotetext{
${ }^{93}$ On bananas and silver, see J. Soluri, 'Accounting for taste: export bananas, mass markets, and Panama disease', Environmental History, 7, 3, 2002, pp. 386-410; J. Soluri, Banana cultures: agriculture, consumption, and environmental change in Honduras and the United States, Austin, TX: University of Texas Press, 2005; D. Studnicki-Gizbert and D. Schecter, 'The environmental dynamics of a colonial fuel-rush: silver mining and deforestation in New Spain, 1522 to 1810', Environmental History, 15, 2010, pp. 94-119. On Cuban sugar, see R. Funes Monzote, 'Deforestation and sugar in Cuba's centre-east: the case of Camagüey, 1898-1926', in C. Brännström, ed., Territories, commodities and knowledges: Latin American environmental histories in the nineteenth and twentieth centuries, London: Institute for the Study of the Americas, 2004, pp. 148-70. On Brazilian rubber, see W. Dean, Brazil and the struggle for rubber: a study in environmental history, Cambridge: Cambridge University Press, 1987. On coffee, see W. Dean, With broadax and firebrand: the destruction of the Brazilian Atlantic forest, Berkeley, CA: University of California Press 1995. On quebracho, see A. G. Zarrilli, 'El oro rojo: la industria del tanino en Argentina (1890-1950)', Silva Lusitana, 16, 2008, pp. 239-59; G. Gori, La Forestal: la tragedia del quebracho colorado, Buenos Aires: Platina, 1965. On Indian and Philippine timber and plantation crops, see R. P. Tucker, 'The depletion of India's forests under British imperialism: planters, foresters, and peasants in Assam and Kerala', in D. Worster, ed., The ends of the earth: perspectives on modern environmental history, Cambridge: Cambridge University Press, 1988, pp. 118-40; G. Bankoff, 'One island too many: reappraising the extent of deforestation in the Philippines prior to 1946', Journal of Historical Geography, 33, 2, 2007, pp. 314-34. On gutta-percha and tin, see J. Tully, 'A Victorian ecological disaster: imperialism, the telegraph, and gutta-percha', Journal of World History, 20, 4, 2009, pp. 559-79; C. Ross, 'The tin frontier: mining, empire, and environment in Southeast Asia, 1870s-1930s', Environmental History, 19, 2014, pp. 454-79.On ivory, see T. Håkansson, 'The human ecology of world systems in East Africa: the impact of the ivory trade', Human Ecology, 32, 5, 2004, pp. 561-91. On Namibian cattle, see E. Kreike, 'De-globalization and deforestation in colonial Africa: closed markets, the cattle complex, and environmental change in north-central Namibia, 1890-1990', Journal of Southern African Studies, 35, 1, 2009, pp. 81-98. For wool, meat, and seed grass, see T. Brooking and E. Pawson, Seeds of empire: the environmental transformation of New Zealand, London: I.B. Tauris, 2011. For additional references on Latin American commodity exports, see also J. Soluri, C. Leal, and J. A. Pádua, eds., A living past: environmental histories of modern Latin America, New York: Berghahn Books, 2018.

${ }^{94}$ For example, of Brazilian rubber from 1827 to 1985 , in Dean, Brazil.

${ }^{95}$ Tucker, Insatiable appetite; W. Beinart and L. Hughes, Environment and empire, Oxford: Oxford University Press, 2007; C. Ross, Ecology and power in the age of empire: Europe and the transformation of the tropical world, Oxford: Oxford University Press, 2017; see also Richards, Unending frontier.

${ }^{96} \mathrm{D}$. Theodoridis, 'The ecological footprint of early-modern commodities: coefficients of land use per unit of product', Göteborg Papers in Economic History 21, 2017, https:/gupea.ub.gu.se/handle/2077/51684 (consulted 4 February 2019).

${ }^{97}$ M. d. Mar Rubio, C. Yáñez, M. Folchi, and A. Carreras, 'Energy as an indicator of modernization in Latin America, 1890-1925', Economic History Review, 63, 3, 2010, pp. 769-804.

${ }^{98}$ While the export crops of Britain's tropical colonies in the late nineteenth and early twentieth centuries were obviously land-intensive, so were the major imports: cotton goods and grains; see M. Havinden and D. Meredith, Colonialism and development: Britain and its tropical colonies, 1850-1960, London: Routledge 1993. Turning to export crops that show up as tradeembedded factor flows need not imply a corresponding increase in environmental impact, if it simultaneously involves turning away from other activities with a high environmental impact. Compare the shift from swidden farming to commercial arboriculture and imports of foodstuffs in D. Henley, 'Swidden farming as an agent of environmental change: ecological myth and historical reality in Indonesia', Environment and History, 17, 2011, pp. 546-7.
} 
the environmental impact would have been lower or even higher in these tropical countries without trade: that is, if the documented impact of exports exceeded the undocumented relief on the environment from imports. This could be evaluated either as net flows of, for example, trade-embedded land or water actually used in producing both imports and exports, or as the savings from imports, if consumption, counterfactually, had to be supplied from local sources.

\section{Conclusion: moving beyond chronological and geographical provincialism}

The recent boom in global studies of trade-embedded environmental factors is partly fuelled by a narrative of the 'great acceleration' in both globalization and environmental impact. Instead, long-term national studies often lean towards a narrative of the 'great specialization', while studies of peripheral primary product exports are informed rather by narratives of the 'great divergence'.

Advancing beyond these conflicting storylines is difficult because of the way that the respective biases play out in the choice of topics to study. Global studies are biased towards the present and future projections, demonstrating a certain chronological parochialism that is not conducive to large-scale empirical investigations into the past. Pre-1950 national studies are biased towards developed countries, and have so far been very neglectful of less-developed countries. This prohibits expressing well-founded views on the possible inequalities or gains emerging from trade between rich and poor countries. Qualitative studies on the environmental consequences of individual exports from less-developed countries neglect imports, and thereby cannot possibly demonstrate net outward flows of environmental factors. If the bias of long-term studies has something to do with the geographical origins of the researching institutions, and familiarity with original sources, the converse focus on the exports of less-developed country may ironically also reflect a metropolitan perception of peripheral regions only as resource suppliers, rather than as consuming subjects in their own right. The problem is not limited to environmental historians, but exemplifies a more general tendency, having to do with the lesser visibility and higher disaggregation of developing country imports. ${ }^{99}$

The chronological parochialism of global studies, and the respective geographical provincialisms of historical studies, suggest three avenues for progress. In a companion study we make a plea for time in global studies using recently launched databases; ${ }^{100}$ here, we concentrate on the remaining problem of space in long-term national studies and environmental historiography. ${ }^{101}$ The geographical scope of long-term trade-informed or consumption-based national studies needs to be expanded. Following the example of material flow analyses, studies of trade-embedded water, energy, and land could start by expanding to rapidly industrializing but non-European countries (such as the US and Japan). Existing trade-embedded data of imperial centres (UK, Spain) ${ }^{102}$ could be used in studies of their less-developed trade partners (British India, Latin America). Other centres (France and the Netherlands) are still under-represented, but would allow similar expansion (Algeria, Indonesia).

Additional effort may be required to counter the risk of developed country sources and estimates being biased against peripheral local trade. For example, Sugihara's re-estimate of intra-Asian trade in 1840 and 1910 roughly doubles this region's volume of trade in monetary

\footnotetext{
${ }^{99}$ A. Rayes, 'The other side of Argentine foreign trade: sources for the study of imports, 1880-1913', Revista de Historia Económica/Journal of Iberian and Latin American Economic History, 36, 1, 2018, pp. 27-51.

${ }^{100} \mathrm{~B}$. Dedinger and P. Girard, 'Exploring trade globalization in the long run: the RICrado project', Historical Methods, 50, 1 , 2017, pp. 30-48; G. Federico and A. Tena-Junguito, 'World trade, 1800-1938: a new data-set', EHES Working paper 93, 2016, http://www.ehes.org/EHES_93.pdf (consulted 4 February 2019); K. Sugihara, 'Asia in the growth of world trade: a re-interpretation of the "long nineteenth century", in U. Bosma and A. Webster, eds., Commodities, ports and Asian maritime trade since 1750, Basingstoke: Palgrave Macmillan, 2015, pp. 17-58.

${ }^{101}$ See also H. A. Innis, The bias of communication, Toronto: Toronto University Press 1951.

${ }^{102}$ E.g. Theodoridis, 'Ecological footprint'.
} 
terms. ${ }^{103}$ In terms of environmental indicators, a case could be made, based on relative water consumption in 1900, that choosing virtual water over land would raise the importance of intra-Asian trade even more. ${ }^{104}$ Relative to current interest, however, pre-1950 virtual water has been under-studied.

Unfortunately, at present we do not even have reliable long-term production-based (territorial) accounts of environmental impact for much of the less-developed world. This may also hamper many long-term global estimates that are 'hindcasts' (model-based predictions of historical conditions) based on population estimates and assumptions about per capita environmental intensities. For example, current global land-use estimates for 1850 vary between 4,371 and 7,264 million acres, ${ }^{105}$ which implies very different trajectories for the $1850-1950$ period. Some of the uncertainty may be remedied in promising collaborative work that is underway by archaeologists, historians, geographers, palaeoecologists (studying past ecologies), and modellers on land-use and land-cover change. ${ }^{106}$ Students of trade-embedded transfers could join forces with these to produce consumption-based accounts.

Finally, if they wish to help in resolving conflicting opinions and questions surrounding the great acceleration, specialization, and divergence narratives, global, environmental, and world-system historians should make greater efforts to put their arguments into numbers, and, in particular, redirect some of their efforts into less-developed country imports. This has been greatly facilitated by the work put into establishing coefficients of environmental intensity for European traded goods, although these coefficients should also be made more readily and systematically available. ${ }^{107}$

John Brolin has a PhD in Human Ecology and a MA in the History of Ideas, and is currently affiliated to the Economic History Department at Lund University. He has a special interest in trying out theories as interpretative tools in history, particularly in the intersection of economics and global environmental change, and is a specialist in theories of unequal exchange.

Astrid Kander is Professor in Economic History at Lund University and has a wide publication record in environmental history, especially in the interrelations of economic growth, energy, and greenhouse gases. In recent years her interests have been devoted to energy and carbon dioxide emissions embedded in international trade, both during the nineteenth-century industrialization of Europe and in our contemporary world.

\footnotetext{
${ }^{103}$ Sugihara, 'Asia'.

${ }^{104}$ I. A. Shiklomanov and J. C. Rodda, eds., World water resources at the beginning of the twenty-first century, Cambridge: Cambridge University Press, 2003.

${ }^{105}$ K. Klein Goldewijk, A. Beusen, J. Doelman, and E. Stehfest, 'Anthropogenic land use estimates for the Holocene - HYDE 3.2', Earth System Science Data, 9, 2017, p. 948.

${ }^{106}$ See the Past Global Changes, PAGES, LandCover6k working group initiative, http://pastglobalchanges.org/ini/wg/ landcover6k (consulted 4 February 2019).

${ }^{107}$ E.g. Theodoridis, 'Ecological footprint'.
}

Cite this article: Brolin J. and Kander A. 2020. Environmental factors in trade during the great transformation: advancing the geographical coverage before 1950. Journal of Global History 15: 245-267, doi:10.1017/S1740022820000030 